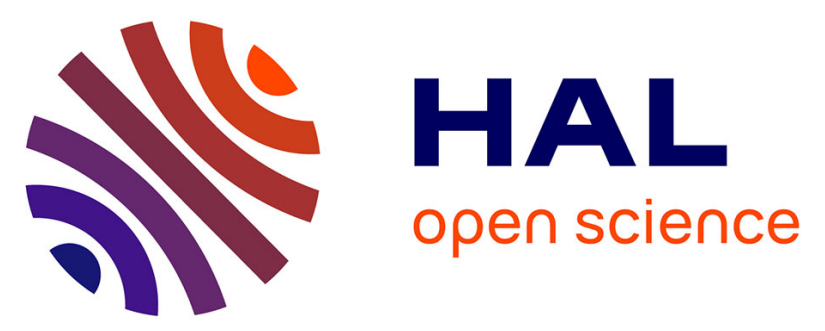

\title{
Deep genetic divergence between austral populations of the red alga Gigartina skottsbergii reveals a cryptic species endemic to the Antarctic continent
}

Emmanuelle Billard, Jeanette Reyes, Andres Mansilla, Sylvain Faugeron, Marie-Laure Guillemin

\section{To cite this version:}

Emmanuelle Billard, Jeanette Reyes, Andres Mansilla, Sylvain Faugeron, Marie-Laure Guillemin. Deep genetic divergence between austral populations of the red alga Gigartina skottsbergii reveals a cryptic species endemic to the Antarctic continent. Polar Biology, 2015, 38 (12), pp.2021-2034. 10.1007/s00300-015-1762-4 . hal-01191026

\section{HAL Id: hal-01191026 \\ https://hal.sorbonne-universite.fr/hal-01191026}

Submitted on 1 Sep 2015

HAL is a multi-disciplinary open access archive for the deposit and dissemination of scientific research documents, whether they are published or not. The documents may come from teaching and research institutions in France or abroad, or from public or private research centers.
L'archive ouverte pluridisciplinaire HAL, est destinée au dépôt et à la diffusion de documents scientifiques de niveau recherche, publiés ou non, émanant des établissements d'enseignement et de recherche français ou étrangers, des laboratoires publics ou privés. 
1 Deep genetic divergence between austral populations of the red alga Gigartina skottsbergii

2 reveals a cryptic species endemic to the Antarctic continent.

3

4 Emmanuelle Billard ${ }^{2}$, Jeanette Reyes ${ }^{1}$, Andres Mansilla ${ }^{3}$, Sylvain Faugeron ${ }^{4,5}$ \& Marie-Laure 5 Guillemin ${ }^{1,5}$.

6

$7 \quad{ }^{1}$ Instituto de Ciencias Ambientales y Evolutivas, Universidad Austral de Chile, Valdivia, Chile.

8 2Univ Porto, CIBIO InBIO, Ctr Invest Biodiversidade \& Recursos Genet, P-4485668 Vairao, 9 Portugal

10 '3aboratorio de Macroalgas Antárticas y Subantárticas and Instituto de Ecología y 11 Biodiversidad (IEB), Universidad de Magallanes, Chile.

$12{ }^{4}$ Centro de Conservación Marina and CeBiB, Facultad de Ciencias Biológicas, Pontificia 13 Universidad Católica de Chile, Santiago, Chile.

$14{ }^{5}$ UMI 3614 Evolutionary Biology and Ecology of Algae, CNRS, Sorbonne Universités UPMC Univ.

Paris 06, Pontificia Universidad Católica de Chile, Universidad Austral de Chile

17 Email: marielaure.guillemin@gmail.com 
21 The almost complete isolation of Antarctica after the intensification the Antarctic Circumpolar

22 Current (ACC) during the middle-Miocene has been challenged by recent molecular data 23 showing the existence of allelic exchange across the ACC. For organisms present on both sides 24 of the ACC, two hypotheses have then been discussed to explain the origin of the Antarctic 25 populations: 1) they correspond to recent immigrants from adjacent continents or 2) they have 26 evolved in situ and have survived the dramatic effects of the last Quaternary glaciations in this 27 region. The red algae Gigartina skottsbergii presents a disjoint distribution and is reported in both Antarctica and southern South America, a distribution pattern that largely exceeds its dispersal capacity. Mitochondrial sequences of the intergenic region cox2-3 $(n=233)$ and partial chloroplastic RuBisCo large subunit gene $(n=26)$ sequences were obtained for individuals from the Chilean sub-Antarctic ecoregion and Antarctic Peninsula localities. The results strongly support the persistence of populations on each side of the Drake Passage during glacial periods and the existence of dispersal barrier due to the ACC. On both sides of the ACC, the last Quaternary glaciations have induced strong bottlenecks that were followed by rapid colonization events. 
Introduction al. 2005).

The Southern Ocean is characterized by high levels of endemism of its fauna and flora (Clarke and Crame 1989; Brandt et al 1999; Clarke and Johnston 2003; Wulff et al. 2009) that has been related to the progressive isolation of the continent during the Mesozoic and the reinforcement of the Antarctic Circumpolar Current (ACC) during the mid-Miocene (Lawver and Gahagan 1998; Rogers et al. 2007; Poulin et al. 2014). Moreover, after the onset of icehouse conditions in Antarctic, both the radiation of groups that have adapted to this extreme environment and allopatric speciation driven by population fragmentation in Antarctic refugia during glacial period seem to have contributed to the high Antarctic diversity (Rogers et al. 2007; Thatje et al. 2008). Recent molecular data for several marine invertebrate taxa, especially those with strong dispersal capabilities, have shown that divergence between Antarctic and South American populations or sister species could be much more recent than the physical separation of the continental landmasses and may rather have been driven by more recent geographic and oceanographic changes like the evolution of the Scotia Arc and the deepening of the Drake Passage (González-Wevar et al. 2012a; Poulin et al. 2014). The ACC is generally considered to act as an impervious hydrographic barrier for most marine species (Clarke et al. 2005; Thatje et al. 2005). Indeed, many studies have shown the absence of gene flow between lineages across the ACC (Krabbe et al. 2010; Janosik et al. 2011; Stupnikova et al. 2013; Poulin et al. 2014; Weis et al. 2014). However, the permeability of this barrier has been questioned by recent studies since low levels of exchanges across the ACC have been observed for spider crabs (Clarke et al. 2005), ribbon worms (Mahon et al. 2010) and the sea star Odontaster meridionalis (Janosik et al. 2011). These new evidences of the ability of species to permeate the Polar Front have raised questions about the importance of historical land mass connectivity versus more recent exchanges across the ACC in driving the distribution of the Southern Ocean benthic biota (Thatje and Fuentes 2003; Tavares and De Melo 2004; Clarke et 

particularly puzzling when considering the major Quaternary climatic oscillations, which led to the formation of an ice-sheet reaching the limits of the continental plateau and likely eradicating life in shallow subtidal areas (Thatje et al. 2005). Many invertebrates are highly abundant and diverse along the Antarctic coasts (Clarke and Crame 1989; Clarke and Johnston 2003; Linse et al. 2006; Aronson et al. 2007; Rogers et al. 2007), suggesting that major climatic and oceanographic changes in the region did not impede their evolutionary success (Clarke and Crame 1989; Aronson et al. 2007). Several hypotheses have been proposed to explain the occurrence of such diversity despite major changes in habitat availability. The "deep-sea refugia" model proposes that species of the Antarctic shelf shifted their bathymetric range toward the deep sea during events of maximum ice cover, and later recolonized shelf areas following the deglaciation process (Kussakin 1973; Thatje et al. 2005; Allcock and Strugnell 2012). This hypothesis has been proposed for invertebrate species with wide eurybathic ranges, and has been confirmed by phylogeographic analyses (e.g. the crinoid Promachocrinus kerguelensis; Hemery et al. 2012). However, the model is not applicable to shallow benthic species, such as seaweeds and herbivores that feed on them, due to their dependence on light availability. Two alternative hypotheses, the "shelf in situ refugia" and the "island refugia" models, propose that some species might have survived in situ either because ice did not cover the entire shelf area at the same time, or alternatively because organisms sought refuge outside of the Antarctic continental shelf in more or less distantly surrounding islands (Thatje et al. 2005; Raupach et al 2010; Diaz et al. 2012; González-Wevar et al. 2013).

In parallel, sub-Antarctic species have also experienced important changes in their respective distribution ranges due to Quaternary glacial cycles. During the Last Glacial Maximum (LGM), the southern tip of South America was covered by the Patagonian ice-sheet that extended approximately from Chiloé Island $\left(42^{\circ} \mathrm{S}\right)$ to the Fuegian low lands $\left(56^{\circ} \mathrm{S}\right)$ (Hulton et al. 2002), and this had various effects on species of southern Chile and Argentina 
(Valdovinos et al. 2003; Aguirre et al. 2013). However, coastal ice-sheets were absent in the Cape Horn region and along the Scotia Arc (Hulton et al. 1994, 2002; Fraser et al. 2012); this likely offered glacial refugia for marine species. Contrasting postglacial recolonization pathways have been inferred from the genetic evidence of several Patagonian species (González-Wevar et al. 2012a). Similarly, several terrestrial species including amphibians, river fish, mammals and plants were restricted to glacial refugia or became locally extinct, whereas others persisted in situ (i.e. in the areas putatively covered by ice-sheets; Jakob et al. 2009; Vianna et al. 2011; Zemlak et al. 2011; Fraser et al. 2012). To date few studies have focused on marine Patagonian species and the existing results indicated diverse scenarios. These scenarios include potential post-glacial recolonization from distant Sub-Antarctic sources (e.g. Durvillaea antarctica, Fraser et al. 2010), from northern, unglaciated regions (e.g. Mazzaella laminarioides, Montecinos et al. 2012), or from local refugia in the southern sub-Antarctic region (Valdovinos et al. 2003). The potential occurrence of glacial refugia between Cape Horn and the South Sandwich archipelagos raises questions about the origin of both sub-Antarctic and Antarctic diversity.

With its present distribution embracing the southern coast (up to $40^{\circ} \mathrm{S}$ ) of Chile and Argentina, sub Antarctic islands (Falkland Islands), Antarctic Islands (South Shetland, South Orkney Islands and South Georgia) and the Antarctic Peninsula, the red alga Gigartina skottsbergii is a suitable model to investigate the impact of major climatic changes on the subtidal flora in high southern latitudes. This species is highly patchy, with populations generally less than a square kilometer in size (Ramirez and Santelices 1991). It belongs to the order Gigartinales, which appears to have originated on Antarctic coasts when this continent was still attached to Australasia and South America (Hommersand et al. 1994). The northern limit of $G$. skottsbergii's distribution is set by contrasting topological and oceanic characteristics including changes in the seawater surface temperature (i.e. the transition between cold waters to more temperate ones) (Ramirez and Santelices 1991). This 
carraghenophyte alga is pseudo-perennial (Wiencke and Clayton 2002) and blades may reach

122 up to $1-2 \mathrm{~m}$ in diameter (Santelices 1988). G. skottsbergii is haploid-diploid and both phases of

123 the isomorphic life cycle coexist in time and space (Piriz 1996; Avila et al. 1999; Westermeier et

124 al. 1999). Propagation is achieved through sexual reproduction (Avila et al. 1999). Antarctic specimens are separated from South American plants by more than $2 \% r b c L$ base pair distance (Hommersand and Fredericq 2003), which is not uncommon among species within red algae (e.g. Gavio and Fredericq 2002). Furthermore, Antarctic and sub-Antarctic populations show physiological differences: while in Antarctica spores germinate at $0^{\circ} \mathrm{C}$ and juveniles grow only at temperatures below $5^{\circ} \mathrm{C}$ (Bischoff-Bäsmann and Wiencke 1996), spores from sub-Antarctic populations do not germinate at $0^{\circ} \mathrm{C}$ and can grow at up to $15^{\circ} \mathrm{C}$ (Buschmann et al. 1999) which might result from an adaptation to regional environmental conditions. These first genetic and physiological results suggest that there is some evolutionary divergence between Gigartina populations from Antarctica and South America. The objective of this study is to infer the evolutionary history of sub-Antarctic and Antarctic populations of the red alga $G$. skottsbergii (Setchell et Gardner) using mitochondrial and chloroplast markers Cox2-3 and rbcL. Two main processes were investigated: the divergence between Antarctic and South American populations, and the genetic consequences of last glacial cycle on both continents.

Materials and Methods.

Sampling-Samples were collected by autonomous diving in the shallow subtidal zones and includes a total of 233 individuals of G. skottsbergii. Samples were extracted from 18 localities covering most of the distribution range of the species (Chilean and Antarctic coasts; Table 1). In order to avoid sampling genetically identical ramets we sampled fronds from distinct holdfasts. Individuals were sampled from the lower littoral down to the depth of $25 \mathrm{~m}$. 
Each individual tissue sample was cut from a clean healthy frond and placed into a plastic bag filled with silica beds for rapid dehydration and preservation of DNA. DNA extraction, PCR amplification and sequencing- Dried algal tissue was finely grounded using liquid nitrogen and DNA was extracted using the phenol-chloroform method described in Faugeron et al. (2001). The Cox2-3, an intergenic non-coding mitochondrial region located between the genes for cytochrome oxidase subunit 2 (COX2) and 3 (COX3) was amplified following Zuccarello et al. (1999). In total, 233 sequences of approximately $350 \mathrm{bp}$ were obtained. Additionally, we amplified a $971 \mathrm{bp}$ region of the chloroplastic gene $r b c \mathrm{~L}$, encoding the large subunit of the ribulose-1,5-bisphosphate carboxylase/oxygenase (RUBISCO) enzyme, using the primers F-rbcL and R-rbcL (Hommersand et al. 1994) and the PCR conditions described by Fredericq and Lopez-Bautista (2002). Sequences were obtained for a sub-sample of 26 individuals (Table 1) for the $r b c L$ gene. All PCR reactions were performed in a Gene Amp PCR system 9700 (Applied Biosystems, Foster City, USA). The amplified samples from each individual were purified with the UltraCleanTM kit (MO BIO Laboratories, Carlsbad, USA) and sequenced in both directions by Macrogen Inc. (Seoul, South Korea). Sequences were edited using Chromas v. 2.33 (McCarthy 1997) and alignments were obtained using the CLUSTAL function of Mega v 5 (Tamura et al. 2011). Sequences were deposited in Genbank with accession numbers KM261841 to KM261858 for the Cox2-3 region and accession numbers KM261859 to KM261862 for the $r b c L$ region. Alignments of the sequences used for the Cox2-3 region and the $r b c L$ for phylogenetic reconstructions are available in Online Resources 1 and 2, respectively.

For the $r b c L$ and the coding part of the Cox2-3 sequences obtained, the McDonaldKreitman test (http://mkt.uab.es, Egea et al. 2008) was performed to detect selection. The neutrality index (NI) was calculated as follows: $\mathrm{NI}=(\mathrm{Pn} / \mathrm{Ps}) /(\mathrm{Dn} / \mathrm{Ds})$, where $\mathrm{P}$ is the polymorphism within the population, $D$ is the divergence or fixed difference between populations, $\mathrm{n}$ is for non synonymous and $\mathrm{s}$ is for synonymous mutations. 
172 reconstructions for each marker dataset were performed with the Maximum Likelihood (ML)

173 method using TreeFinder v March 2011 (Jobb et al. 2004) and a Bayesian inference (BI) using

174 MrBayes v 3.1.2 (Huelsenbeck and Ronquist 2001). Outgroup species belonging to the genus

175 Sarcothalia and Iridaea were chosen since they represent the closest known sister-taxa of

176 Gigartina skottsbergii in the phylogenetic systematics of the Gigartinaceae (Hommersand et al.

177 1999). Outgroup sequences considered for the $r b c L$ consisted of four species of Sarcothalia (S. and two sequences of Iridaea cordata from Antarctica (U02989 and GQ323780). For the cox23, two sequences of S. crispata (KM275591 and KM275592, both from Punta Estaquilla) and one sequence of I. cordata (KM275593 from Punta Hanna, South Shetland Islands) were used as outgroup. We also included in the analyses available $r b c L$ sequences for $G$. skottsbergii (U03432, Ancud, Chile and AF146206, King George Island, South Shetland Islands; Hommersand et al. 1999). For both phylogenetic reconstruction methods, large indels within the non-coding intergenic region of the Cox2-3 were treated as single mutation events. $M L$ analyses were performed using a mixed model taking into account the position of codons for the $r b c \mathrm{~L}$ gene while only one model was used for the cox2-3 intergenic region analysis. TreeFinder v March 2011 (Jobb et al. 2004) allows to choose between 32 substitution models for each partition of the data set. The best-fitted substitution models were selected using the Akaike Information Criterion implemented in the ModelTest package of the TreeFinder program (Posada and Crandall 1998; Jobb et al. 2004). The selected models for the $r b c \mathrm{~L}$ data were $\mathrm{TN}+\mathrm{G}$ for the first codon position, $\mathrm{HKY}+\mathrm{G}$ for the second codon position and $J 3+G$ for the third codon position. For cox2-3 the selected model was $H K Y+G$. Using TreeFinder v March 2011, we performed a heuristic search in order to reconstruct the trees and node supports were assessed by non-parametric bootstrapping (1000 pseudo-replicates, Felsenstein 1985). 

parameters defined for each dataset. Four independent analyses were run with four chains each ( 3 heated chains and one "cold" chain) for ten million generations. The settings were a heating parameter value of 0.2 and sampling every 1000 generations with randomly generated starting trees. The first $25 \%$ of sampled trees were discarded as "burn-in" to ensure convergence. The remaining trees were used to compute a consensus topology and posterior probability values. The split frequency (variance between the four independent runs) was below 0.0005 , confirming that the posterior probability distribution was accurately sampled. Because the posterior probability bootstrap values were essentially identical in the independent runs starting from different, random topologies, we considered that the chains had converged.

Even though the lack of fossils impedes a precise calibration of molecular clocks in red algae, we used divergence rates already published for this group to estimate the historical divergence event between South American and Antarctic populations. A divergence rate of 0.109-0.127\% per site per million years (Myr) has been proposed for $r b c L$ (Kamiya et al. 2004). For cox2-3, a site mutation rate of $0.756-0.426 \%$ per Myr, based on the divergence of the red algae Asparagopsis spp. associated to the Panama isthmus closure, was proposed by Andreakis et al. (2007). Divergence time was estimated in BEAST v1.8 (Drummond et al. 2012) using the Yule model of tree prior, a gamma site heterogeneity model to allow variation among sites of the mutation rate, and a Log-normal relaxed clock with a uniform sampling within the range of published mutation rates. Four runs of ten millions MCMC iterations each were performed and the combined results were analyzed with Tracer v1.8 (Drummond et al. 2012). Effective sample size of the posterior distribution, the parameter of accuracy of the parameter estimation, was always superior to 300 in each individual run and in the combined analyses, indicating the MCMC appropriately converged to estimated values. 
223 location and for the two phylogenetic lineages (i.e. G. skottsbergii from Chile and the Falkland Islands and G. skottsbergii from sub-Antarctic and Antarctic) using Arlequin v 3.5 (Excoffier and Lisher 2010): the number of haplotypes $(\mathrm{nH})$; the number of private haplotypes (i.e. haplotypes found in a single population, nHpriv); the number of polymorphic sites (S); gene diversity (Hd, Nei 1987) and nucleotide diversity ( $\pi$, Nei and Li 1979). For $r b c$, only nH was calculated.

Network reconstruction and historical demography - Haplotype networks were reconstructed for cox2-3 using the median-joining algorithm implemented in NETWORK $v$ 4.510 (Bandelt et al. 1999). Moreover, for this molecular marker, three complementary approaches were used to infer the historical demography of G. skottsbergii from Chile and the Falkland Islands.

First, Tajima's D (Tajima 1989) and Fu's Fs (Fu 1997) statistics were calculated to detect significant past changes in population size. Significant departure from mutation-drift equilibrium was tested by 1000 bootstrap replicates in Arlequin (Excoffier and Lisher 2010). Under the assumption of neutrality, negative values characterize populations in expansion while positive values, associated with the loss of rare haplotypes, are considered as a signature of recent bottlenecks (Tajima 1989, Fu 1997). Second, the observed distributions of pairwise differences were compared to estimated values under a model of sudden pure demographic expansion (Roger and Harpending 1992) using Arlequin (Excoffier and Lisher 2010). The model fit between the observed and estimated mismatch distributions was calculated through a generalized least squares approach, which was then tested with 1000 permutations. The date of growth/decline $245(\tau=2 \mu \mathrm{t})$, measured in units of $1 / 2 \mu$ generations where $t=$ time in years and $\mu=$ mutation rate per sequence per generation, was estimated using the demographic expansion parameters as 
determined in the nonlinear least squares approach implemented in Arlequin (Excoffier and Lisher 2010).

Third, population growth rate and timing was estimated from coalescent simulations implemented in LAMARC 2.1.9 (Kuhner 2006). The maximum likelihood approach was applied using the Metropolis-coupled Markov chain Monte Carlo (MCMC) method with replication of chains and adaptive heating to achieve optimal sampling of the parameter space. The MCMC runs were performed three times with random seeds; each run used 10 initial chains with 500 samples and two long final chains with 10000 samples. All initial chains and final chains were simulated using a sampling interval of 20 and a burn-in of 1000 samples. A tenfold evolutionary rate (4.26-7.56\% per million years) was considered at population level, following the correction for time dependence of molecular rate proposed by Ho et al. (2011).

Results.

Four chlorotypes were detected for the chloroplast marker $r b c \mathrm{~L}$, with 23 polymorphic sites along the 971 base pair fragments sequenced (11 sequenced individuals, Table 1 ). For the cox2-3 mitochondrial marker, 18 mitotypes were observed (233 sequenced individuals, Table 1). For this marker, 48 polymorphic sites were observed including two indels: one indel of $1 \mathrm{bp}$ characteristic of the mitotype $\mathrm{C} 13$ and one indel of $12 \mathrm{bp}$ for mitotypes $\mathrm{C} 8$ and $\mathrm{C} 17$. Sequence length of cox2-3 sequences varied from 337 to $350 \mathrm{bp}$.

Figure 1 shows the Maximum Likelihood (ML) phylogenetic trees constructed using the two molecular markers. For both markers, tree topologies based on Bayesian and ML analyses were largely congruent and shared comparable support values for major nodes (Figure 1). Regardless of the marker used, tree topologies were broadly similar among phylogenetic reconstruction methods and clearly showed that all G. skottsbergii sequences obtained in this 
support values $>89 \%$ ) that are strongly divergent from the outgroup species. The first lineage is

273 composed of all individuals from Chile and the Falkland Islands while the second is composed

274 of individuals from the Antarctic Peninsula, the South Shetland Islands and the South Orkney Islands (Figure 1). The available rbcL sequence AF146206 in GenBank for G. skottsbergii previously sampled in King George Island in the South Shetland Islands (Hommersand et al. 1999) corresponds exactly to the chlorotype R4 present in our Antarctic lineage. The uncorrected p-distance, measured using only 665bp, between the $r b c L$ sequence U03432 and the closest sequence in our data set (i.e. chlorotype R1, present only in Ancud, Chile, see Table 1 ) is of $0.3 \%$. This is congruent with the location where the specimen corresponding to the U03432 sequence was collected, on Chiloé Island within the bay of Ancud (Hommersand et al. 1999). P distances between sequences from the Antarctic and South American G. skottsbergii lineages were of $9.2 \pm 1.5 \%$ for cox $2-3$ and of $2.1 \pm 0.5 \%$ for $r b c L$. When performed between the Antarctic and South American G. skottsbergii lineages, no significant departure from neutrality was detected using the McDonald-Kreitman test for the $r b c L$ and the coding part of Cox2-3, respectively). estimated at 9.4 Myr (95\% Cl: 3.2-16.4Myr) based on cox2-3 data and at $14.9 \mathrm{Myr}$ (95\% Cl: 2.635.9Myr) based on $r b c L$ data.

For both markers, no genetic diversity was observed in the Antarctic lineage of $G$. skottsbergii. Only one haplotype was detected for the cox2-3 region and for the $r b c \mathrm{~L}$ gene, the mitotype C18 and the chlorotype R4, respectively (Table 1). The Antarctic lineage is spread over more than $1600 \mathrm{~km}$ of coast, from Marguerite Bay (67 $\mathrm{S})$ to the South Orkney Islands $\left(60^{\circ} \mathrm{S}\right)$ (Table 1, Figure $\left.2 \mathrm{C}\right)$. Within the South American lineage of G. skottsbergii the genetic diversity in cox2-3 was generally low with the number of mitotypes per sampling site $(\mathrm{nH})$ 

populations (Table 1). The highest genetic diversity was observed in the population of PAG, $\mathrm{BCH}$ and $\mathrm{FAL}(\mathrm{nH}=5$ and $\mathrm{Hd}>0.5$ in all three populations, Table 1). These three populations were also the ones with the highest number of private haplotypes, with three private haplotypes in PAG and FAL and two in BCH (Table 1). For the $r b c \mathrm{~L}$ gene, only three chlorotypes were observed within the South American lineage of G. skottsbergii. Only one chlorotype was found in each single population and the only private chlorotype (R1) was observed in the ANC population (Table 1). The chlorotype R3 was shared between BOR in Tierra del Fuego and FAL located in the Falkland Islands (Table 1).

The cox2-3 mitotype network revealed the presence of two main haplogroups, one for South America and one for Antarctica, which are separated by 31 bp (Figure 2A), a result fully congruent with the phylogenetic reconstructions (Figure 1). Within the South American haplogroup, characterized by a typical star-like topology, pairs of mitotypes were separated by 1 to $5 \mathrm{bp}$, except for the mitotypes $\mathrm{C} 17$ and $\mathrm{C} 8$ that were differentiated by a unique $12 \mathrm{bp}$ indel. This haplogroup is also characterized by one frequent and widespread mitotype (C1, 81\% of the samples, Table 1) and several less frequent mitotypes (Figure 2A). Low frequency mitotypes were predominantly restricted to a single or few nearby local populations. For example, the mitotype C3 was observed in BLO and PAG, these being two populations located in the Moraleda Channel. Additionally, mitotype $\mathrm{C} 7$ was observed in $\mathrm{BCH}, \mathrm{BOR}$ and TOR which are located in the southern part of the Magellanic region and Tierra del Fuego (Figure 2B). One mitotype, $\mathrm{C} 13$, was also shared between $\mathrm{BCH}$ in the southern part of the Magellanic region and FAL located in the Falkland Islands (Figure 2B). As expected, the star-like topology is coupled with a unimodal mismatch distribution (Figure $3 \mathrm{~A}$ ), and the values of Tajima's $D$ and Fu's Fs statistics were both negative and significant $\left(D=-2.01, p=0.001 ; F_{s}=-1.26, p=0.0001\right) a$ result congruent with a sudden demographic population expansion model. Population size changes depicted from the mismatch distribution was $\tau=0.73$ (90\% confidence interval of 0.00 
to 2.23). Assuming the start of exponential demographic expansion when population size was

$3241 \%$ of present-day's estimate, it was estimated to initiate $20000-36000$ years before present.

325 A large positive exponential growth rate, $g=3004$ (2458-4666 95\% confidence interval), was

326 also detected. It is possible that demographic expansion led to a large increase in $\mathrm{Ne}$

327 (approximately 170000 to 300000 -fold increase, Fig. 3B), which may have started during or

328 just before the LGM, depending on the combination of growth and mutation rates considered

329 within their respective confidence limits.

Discussion

The patterns of genetic structure for $G$. skottsbergii seem to confirm the absence of gene flow between Antarctic and South American populations. Regardless of the marker analyzed, phylogenetic reconstructions using mtDNA and cpDNA sequences showed strong congruence and clear support for two distinct lineages consisting of populations from South America and the Falklands on the one hand and populations from the Antarctic Peninsula, Shetlands and Orkney Islands on the other hand. The absence of shared haplotypes between the two regions may reflect the isolation created by the Antarctic Circumpolar Current between the Antarctic Peninsula and the South American continent. Divergences among lineages of G. skottsbergii for the Cox2-3 $(9.2 \pm 1.5 \%)$ and for the $r b c \mathrm{~L}(2.1 \pm 0.5 \%)$ are within the range reported for interspecific distances between sister species in Rhodophyta (ranging from $2.55 \%$ to $4.70 \%$ and from $0.77 \%$ to $5.08 \%$ for the Cox $2-3$ and the $r b c L$, respectively; Mclvor et al. 2001; Destombe et al. 2010; Hernández-Kantún et al. 2014). The large range estimated, of 2.6 to 35.9 My depending on the genetic marker and the mutation rate considered (with central tendency around 9 to $15 \mathrm{My})$, for divergence time between the two lineages seems to predate Pleistocene glaciations. This time of divergence is however more recent than the separation of the Antarctic continent from the South American continent (approximately 24-40 Myr ago), 
and seems to include the period of intensification of the ACC circulation 11-12 Myr ago (Dalziel et al. 2013). These climatic and oceanographic changes have been shown to be major drivers in the isolation of marine Antarctic fauna. For example, González-Wevar et al. (2010) have shown that the diversification within a genus of mollusk (Nacella) took place long after the separation of the continents. For these marine mollusks, the appearance of the most genetically distant clades (Kerguelen, Antarctic, and South America) took place between 9 and 5 Myr. These results were further supported by a recent study of comparative phylogeography of different invertebrate taxa showing a shared Antarctic and South American distribution (GonzálezWevar et al. 2012a; Poulin et al. 2014). In these studies, divergence times between Antarctic and South American lineages ranged from 1.0 to $13.6 \mathrm{Myr}$, largely overlapping the estimates for G. skottsbergii. Interestingly, divergence estimates in the mitochondrial markers for $G$. skottsbergii (9.2\%) fall within the $7-11 \%$ range for shallow subtidal and intertidal invertebrates (González-Wevar et al. 2010, 2012a; Poulin et al. 2014), corroborating the occurrence of a shared evolutionary history despite imprecisions in the respective mutation rates. These authors proposed that the connection between Antarctic and South American populations could have been maintained by a stepping stone process along the archipelago of the Scotia Arc. Indeed, geological evidence has recently been reported of a now-submerged volcanic arc in the Central Scotia Sea that existed during the early Miocene (Dalziel et al. 2013). This archipelago was located closer to the Antarctic Peninsula and the Cape Horn region than the South Sandwich Islands are today, and may thus have provided a corridor for genetic connectivity across the Drake Passage until approximately 10-11 Myr ago (Poulin et al. 2014). Our study further shows that G. skottsbergii, a seaweed characterized by a very restricted dispersal capacity of its spores, may also have maintained a certain level of connectivity (even after the mid-Miocene) between the continents of Antarctica and South America through the volcanic arc of islands linking both sides of the Scotia Sea. This connection could have been 
374 invertebrates, through rafting of adults (Nikula et al. 2010; Haye et al. 2012; Poulin et al. 2014).

375 The Antarctic and South American lineages of G. skottsbergii exhibit different patterns of genetic diversity. While a strong demographic expansion was inferred in the sub-Antarctic region, a total absence of genetic diversity was observed in the Antarctic lineage. The presence of a single haplotype over more than $1600 \mathrm{~km}$ from Marguerite Bay to the South Orkney Islands is intriguing. Even if this lack of diversity limits our capacity to test for different demographic scenarios in Antarctica, it suggests that a very strong demographic bottleneck occurred during glacial contraction, followed by a sudden and recent recolonization process that did not allow for new mutations. Similarly, the overall low genetic diversity and the presence of the same common haplotype C1 in every population from the Chilean coast to the Falkland Islands seems to support the hypothesis of persistence in a single glacial refugium followed by a massive demographic expansion over $2500 \mathrm{~km}$. Such a pattern of genetic homogeneity over a broad geographical range has usually been related to high dispersal potential (Bortolotto et al. 2011; González-Wevar et al. 2012b). The scenario of rapid recolonization leading to the presence of only one haplotype over thousands of kilometers of coast is, however, difficult to envision for G. skottsbergii. Indeed, this alga is a non-buoyant species, and spore dispersal is considered to be very limited (Ramirez and Santelices 1991). Nevertheless, signatures of long distance dispersal have been observed in other apparently non-dispersive algal species like Adenocystis utricularis or Bostrychia intricata and have been explained by the organisms' potential ability to raft on floating substrates (Fraser et al. 2010, 2013). In contrast with our results, in a previous study using RAPDs nuclear markers (Faugeron et al. 2004), significant genetic differentiation among South American populations was observed and has been related to the poor dispersal capacity of for G. skottsbergii. Differences in mutation rates and/or level of drift effects (effective population size of uniparentally inherited loci is only one-fourth that of nuclear loci) may account for the differences between 
level of genetic structure obtained with RAPDs (Faugeron et al. 2004) and cytoplasmic

400 sequences (our study). Also, during spatial expansion, gene surfing effects may contribute to the reduction of diversity in cytoplasmic markers in the recolonized region (Excoffier and Ray 2008). Indeed, large-scale spread of mitochondrial genetic variants has been observed during recolonization process in seaweeds (Fraser et al. 2010). The ACC is a strong west to east current that connects the Antarctic Peninsula and the South Shetland Islands to the Antarctic Islands located in the South Scotia Ridge. Particle movement modeling and particle tracking has shown that passive drifters travel northeastwards across the Scotia Sea, connecting the Antarctic Peninsula and the South Shetland Islands to South Orkney Islands and South Georgia (Thorpe et al. 2004). Movement of drifting seaweed along the ACC could be connected to west-east spatial expansion pattern. On the other hand, the postglacial colonization of the Peninsula could have been promoted by stepwise spatial expansion through spore propagation. Such spatial expansion could have been facilitated by strong coastal currents, as the Antarctic Peninsula Coastal Current (APCC; Moffat et al. 2008), a southward current that

413 forms during the ice-free seasons and extends to Alexander Island. However, we lack knowledge on the actual mechanisms of dispersal in G. skottbergii to appropriately determine the role of dispersal during post-glacial population dynamics on the present day genetic diversity.

The location of both Antarctic and South American glacial refugia is difficult to infer from the results presented here. The extreme genetic homogeneity within the G. skottsbergii Antarctic clade is in disagreement with the hypothesis that genetic structure and global genetic diversity in Antarctica may have been promoted by the fragmentation and isolation of micro-refugia where marine species were able to survive during repeated ice advances and retreats (Thatje et al. 2005; Allcock and Strugnell 2012). The possible presence of micro-refugia has been particularly highlighted in the archipelagoes located near the West Antarctic Peninsula and the 
data have shown that the South Shetland Islands is the most speciose region for endemic

426 Southern Ocean octopuses of the genus Pareledone (Allcock et al. 2011). Even though the data

427 herein lack the explicit molecular diversity to test adequately for the number and location of glacial refugees in this region, the survival of $G$. skottsbergii during the LGM seems more likely in the northernmost latitude (South Shetland and South Orkney Islands). Indeed, whereas G. skottsbergii is found in dense beds within these northern archipelagos, less than ten specimens could be collected in Paradise Bay and only one specimen was sampled in Marguerite Bay (Note that the same sampling effort was applied in Paradise Bay, Marguerite Bay, O'Higgings and Punta Prat; Table 1; M-L Guillemin, personal communication). It is understood that an increased sampling effort could better elucidate the southern limits of $G$. skottsbergii, but it seems that in Marguerite Bay the alga has reached a biotic or abiotic limit to its distribution.

The absence of genetic structure for the mitochondrial and chloroplast markers in southern South America also limits our ability to infer the number and location of glacial refugia. Because of their longstanding demographic stability, populations from glacial refugia are expected to present higher levels of genetic diversity than those populations that have formed following postglacial expansions (Provan and Bennett 2008). In addition, long-term isolation in distant refugia often leads to genetic differentiation due to mutation accumulation and genetic drift (Hewitt 2000). Along the Chilean coast, recolonization pathways have differed between organisms in terms of the number and origin of sources. A recent recolonization from a single distant/exterior source has been proposed to explain the high genetic homogeneity of populations of the red alga Mazaella laminarioides (Montecinos et al. 2012) and the brown alga Durvillaea antarctica that exist south of $42^{\circ} \mathrm{S}$ (Fraser et al. 2010). In M. laminarioides, a single refugium has been proposed, located in the North of the Island of Chiloe and the mainland coast north of the $41^{\circ} \mathrm{S}$ (Montecinos et al. 2012). In D. antarctica, broad sampling across the southern hemisphere has shown that all individuals present off the Patagonian coast of Chile share the same haplotype (Fraser et al. 2010) and the authors have indicated 
451 that this species likely recolonized the region from a refugium in New Zealand sub-Antarctic

452 archipelagoes. Yet others have highlighted the role that the Southern Fjords and Channels

453 Region played as a refuge for several animal species, like marine mollusks (Valdovinos et al.

454 2003; González-Wevar et al. 2010) and the river otter (Vianna et al. 2011). The existence of

455 multiple refugia, scattered among the Southern Fjords and Channels, has been proposed to

456 explain the high levels of endemism and the high diversity of mollusks in this region

457 (Valdovinos et al. 2003). In G. skottsbergii, the overall low genetic diversity and the presence of the same common haplotype, $\mathrm{C} 1$, in every population from the Chilean coast to the Drake Passage and the Falkland Islands seem to support the hypothesis of a single glacial refugium. Strong currents (i.e. the Cape Horn Current and the Malvinas-Falkland Current) connect the southern coast of Chile from $42^{\circ} \mathrm{S}$ to Cape Horn and the Falkland Islands. These currents have been shown to provide high connectivity among all inhabiting regions for the genus Nacella

463 (González-Wevar et al. 2012b). In this genus, the existence of asymmetric gene flow, from 464 West to East, was shown to be related to the prevailing circulation patterns in this region 465 (González-Wevar et al. 2012b). Due to these strong directional currents, the hypothesis of a postglacial recolonization of the Chilean coast by G. skottsbergii from a refuge located in the Falkland Islands is most unlikely. Again, more polymorphic markers should help identifying regions with higher / lower genetic diversity as putative locations of glacial refugia / recolonized areas, respectively, for $G$. skottsbergii.

In accordance with previous results of Hommersand et al. (2009) the data presented here clearly show two divergent and respectively monophyletic clades of G. skottsbergii that may correspond to two cryptic species. G. skottsbergii (Type locality: Slogget Bay, Fuegia - Silva 
476 Chile and the Falkland Islands. The Antarctic species, still to be formally described and named,

477 occurs in the Antarctic Peninsula, the South Shetland Islands and the South Orkney Islands.

478 Despite drastic reductions in population size, as revealed by strong signals of bottlenecks, both

479 species persisted and maintained their separation on either side of the ACC even during the

480 glacial period. The divergence time between the two cryptic species, estimated as 9.4 to

481 14.9 Myr (comparable with other invertebrate species, but with a large confidence interval of

482 2.6-35.9Myr), indicates that algae with limited dispersal capabilities were able to cross the

483 Scotia Sea after separation of the continents, potentially via a stepping stone process through

484 the volcanic arc of islands. Our work also sheds light on the possible importance of dispersal by

485 rafting in the recolonization process of a species for which natural propagation is mainly

486 achieved via sexual reproduction (Avila et al. 1999; Westermeier et al. 2012). Future prospects

487 on glacial refugia for Antarctic and sub-Antarctic seaweeds shall also contribute to better

488 understand the dispersal mechanisms during demographic expansion in these regions

489 characterized by complex topography of coastal shelf and coastal currents.

Acknowledgments

This research was supported by the Instituto Antártico Chileno (INACH) project T_16-11. EB is granted by a postdoctoral fellowship from the Project "Genomics Applied To Genetic Resources" cofinanced by North Portugal Regional Operational Programme 2007/2013 (ON.2 -

O Novo Norte), under the National Strategic Reference Framework (NSRF), through the European Regional Development Fund (ERDF). Additional support came from the International Research Network "Diversity, Evolution and Biotechnology of Marine Algae" (GDRI N 0803) and from the CONICYT FONDECYT/REGULAR N 1140940. The authors thank P. Brunning, J. L. Kappes, T. Heran, Y. Henriquez, J. Ojeda and L. Vallejos for their help in the field and M. E. 
501 correction. The authors would also like to thank C. González-Wevar and four anonymous

502 reviewers for their critical comments and valuable suggestions, which helped to improve this

503 manuscript. We also thank the Chilean Navy (especially the captain and crew of the ships

504 Almirante Oscar Viel and Lautaro), the staff from the Chilean Army in the O'Higgins base and

505 the Air Force of Chile (FACh) for the logistic support of our fieldwork in sub-Antarctica and 506 Antarctica.

507 
Figure 1: Maximum likelihood rooted trees for the cox2-3 and the rbcL haplotypes of Gigartina

509 skottsbergii. Maximum likelihood bootstrap values are indicated above each node and 510 Bayesian posterior probabilities are noted between brackets. Only high support values are 511 shown ( $>75$ for bootstraps and $>0.95$ for posterior values, respectively; - correspond to 512 branches not observed in the Bayesian inference reconstruction).

513 Figure 2: Haplotype networks of Gigartina skottsbergii and their geographic distribution based 514 on cox2-3. The haplotype networks are presented in (A) while the pie charts showing the 515 geographical distribution of haplotypes of the South American haplogroup are shown in (B) 516 and the pie charts showing the geographical distribution of haplotypes of the Antarctic haplogoup are shown in (C). In the networks, each circle represents a haplotype and its size is proportional to the frequency in which the haplotype was encountered (correspondence between circle sizes and numbers of individuals is indicated in the box A). The black square inbetween C7, C9 and C14 represents a hypothetical un-sampled haplotype. For haplotypes separated by more than one mutational step, the number of steps is indicated in bp. Pie charts' color-code corresponds to the one used in haplotype networks. Abbreviations for population codes are as in Table 1. Numbers of sequenced individuals are given between brackets.

Figure 3: Mismatch distributions (A) and population growth rate estimates (B) of the South American haplogroup of Gigartina skottsbergii for the cox2-3 marker. Growth rate and timing of population dynamic changes were estimated from coalescent simulations implemented in LAMARC 2.1.9 (Kuhner 2006). The observed distribution of the number of pair base differences between sequences is indicated by the grey bars while the expected distribution under a

530 model of sudden demographic expansion is represented by a black line. Effective population 531 size (i.e. Ne) fluctuations throughout time are represented in the LAMARC graph. The dotted 532 lines represent the $95 \%$ confidence intervals of the estimated growth rate, whereas the grey 
533 shaded area corresponds to the average growth rate combined with the range of mutation

534 rates proposed by Andreakis et al (2007) corrected by a tenfold evolutionary rate as suggested

535 at population level for time dependence of molecular rate by Ho et al. (2011). 
537

538

539

540

541

542

543

544

545

546

547

548

549

550

551

552

553

554

555

556

557

558

559

560

Aguirre ML, Richiano S, Donato M, Farinati EA (2013) Tegula atra (Lesson, 1830) (Mollusca, Gastropoda) in the marine Quaternary of Patagonia (Argentina, SW Atlantic): Biostratigraphical tool and palaeoclimate-palaeoceanographical signal Quatern Int 305:163-187

Allcock AL, Barratt I, Eleaume M, Linse K, Norman MD, Smith PJ, Steinke D, Stevens DW, Strugnell JM (2011) Cryptic speciation and the circumpolarity debate: A case study on endemic Southern Ocean octopuses using the COI barcode of life. Deep-Sea Res II $58: 242-249$

Allcock AL, Strugnell JM (2012) Southern Ocean diversity: new paradigms from molecular ecology. Trends Ecol Evol 27:520-528

Andreakis N, Proccacini G, Maggs C, Kooistra WHCF (2007), Phylogeography of the invasive seaweed Asparagopsis (Bonnemaisoniales, Rhodophyta) reveals cryptic diversity. Mol Ecol 16: 2285-2299

Aronson RB, Thatje S, Clarke A, Peck LS, Blake DB, Wilga CD, Siebel BA (2007) Climate change and Invasibility of the Antarctic Benthos. Annu Rev Ecol Evol Syst 38:129-154

Avila M, Candia A, Nunez M, Romo H (1999) Reproductive biology of Gigartina skottsbergii (Gigartinaceae, Rhodophyta) from Chile. Hydrobiologia 399:149-157

Bandelt HJ, Forster P, Röhl A (1999) Median-Joining networks for inferring intraspecific phylogenies. Mol Biol Evol 16:37-48

Bischoff-Bäsmann B, Wiencke C (1996) Temperature requirements for growth and survival of Antarctic Rhodophyta. J Phycol 32: 525-535

Bortolotto E, Bucklin A, Mezzavilla M, Zane L, Patarnello T (2011) Gone with the currents: lack of genetic differentiation at the circum-continental scale in the Antarctic krill Euphausia superba. BMC Genetics 12:32 
Brandt A, Linse K, Mühlenhardt-Siegel U (1999) Biogeography of Crustacea and Mollusca of the Magellan and Antarctic regions. Sci Mar 63:383-389

Buschmann AH, Correa JA, Westermeier R (1999) Recent advances in the understanding of the biological basis for Gigartina skottsbergii Rhodophyta. cultivation in Chile. Hydrobiologia 398/399: 427-434

Clarke A, Crame JA (1989) The origin of the Southern Oceanmarine fauna. In: Crame JA (Ed) Origins and evolution of the Antarctic biota. Geological Society Special Publications, vol 47. The Geological Society, London

Clarke A, Johnston NM (2003) Antarctic marine benthic diversity. Oceanogr Mar Biol Annu Rev 41:47-114

Clarke A, Barnes DKA, Hodgson DA (2005) How isolated is Antarctica? Trends Ecol Evol 20:1-3

Dalziel IWD, Lawver LA, Norton IO, Gahagan LM (2013) The Scotia Arc: genesis, evolution, global significance. Ann Rev Earth and Planetary Sciences 41:767-793

Destombe C, Valero M, Guillemin M-L (2010) Delineation of two sibling red algal species, Gracilaria gracilis and Gracilaria dura (Gracilariales, Rhodophyta), using multiple DNA markers: Resurrection of the species $G$. dura previously described in the Northern Atlantic 200 years ago. J Phycol 46:720-727

Diaz A, González-Wevar CA, Maturana C, Palma AT, Poulin E, Gerard K (2012) Restricted geographic distribution and low genetic diversity of the brooding sea urchin Abatus agassizii (Spatangoidea: Schizasteridae) in the South Shetland Islands: A bridgehead population before the spread to the northern Antarctic Peninsula? Rev Chil Hist Nat 85:457-468.

Drummond AJ, Suchard MA, Xie D \& Rambaut A (2012) Bayesian phylogenetics with BEAUti and the BEAST 1.7 Mol Biol Evol 29: 1969-1973

Excoffier E, Ray N (2008) Surfing during population expansions promotes genetic revolutions and structuration. Trends Ecol Evol 23:347-351 
587 Excoffier L, Lisher H (2010) Arlequin suite ver 3.5: A new series of programs to perform 588 population genetics analyses under Linux and Windows. Mol Ecol Resour, 10:56

589 Faugeron S, Valero M, Destombe C, Martínez EA, Correa JA (2001) Hierarchical spatial 590 structure and discriminant analysis of genetic diversity in the red alga Mazzaella

Faugeron S, Martinez EA, Correa JA, Cardenas L (2004) Reduced genetic diversity and increased 593 population differentiation in peripheral and overharvested populations of Gigartina skottsbergii (Rhodophyta, Gigartinales) in southern Chile. J Phycol 40:454-462

Felsenstein J (1985) Phylogenies and the comparative methods. Am Nat 125:1-15

Fraser Cl, Thiel M, Spencer HG, Waters JM (2010) Contemporary habitat discontinuity and historic glacial ice drive genetic divergence in Chilean kelp. BMC Evol Biol 10:12

Fraser Cl, Nikula R, Ruzzante DE, Waters JM (2012) Poleward bound: biological impacts of Southern Hemisphere glaciation. Trends Ecol Evol 27:462-471

Fraser Cl, Zuccarello GC, Spencer HG, Salvatore LC, Garcia GR, Waters JM (2013) Genetic affinities between trans-oceanic populations of non-buoyant macroalgae in the high latitudes of the Southern Hemisphere. PlosONE 8:7

Fredericq S, Lopez-Bautista J (2002) Characterization and phylogenetic position of the red alga 604 605 Besa papillaeformis Setchell: an example of progenetic heterochrony? Constancea

Fu YX (1997) Statistical tests of neutrality of mutations against population growth, hitchhiking 607 and background selection. Genetics 147:915-925

Gavio B, Fredericq S (2002) Grateloupia turuturu (Halymeniaceae, Rhodophyta) is the correct 609 name of the nonnative species in the Atlantic known as Grateloupia doryphora. Eur J Phycol 37:349-359 
González-Wevar CA, Nakano T, Cañete JI, Poulin E (2010) Molecular phylogeny and historical biogeography of Nacella (Patellogastropoda: Nacellidae) in the Southern Ocean. Mol Phy Evol 56:115-124

González-Wevar CA, Diaz A, Gerard K, Cañete JL, Poulin E (2012a) Divergence time estimations and contrasting patterns of genetic diversity between Antarctic and southern South America benthic invertebrates. Rev Chil Hist Nat 85:445-456

González-Wevar CA, Hune M, Cañete JI, Mansilla A, Nakano T, Poulin E (2012b) Towards a model of postglacial biogeography in shallow marine species along the Patagonian Province: lessons from the limpet Nacella magellanica (Gmelin, 1791). BMC Evol Biol $12: 1$

González-Wevar CA, Saucède T, Morlay SA, Chown SL, Poulin E (2013) Extinction and recolonization of maritime Antarctica in the limpet Nacella concinna (Strebel, 1908) during the last glacial cycle: toward a model of Quaternary biogeography in shallow Antarctic invertebrates. Mol Ecol 22: 5221-5236

Haye PA, Varela Al, Thiel M (2012) Genetic signatures of rafting dispersal in algal-dwelling brooders Limnoria spp. (Isopoda) along the SE Pacific (Chile). Mar Ecol Prog Ser 455:111-122

Hemery LG, Eléaume M, Roussel V, Améziane N, Gallut C, Steinke D, Cruaud C, Couloux A, Wilson NG (2012) Comprehensive sampling reveals circumpolarity and sympatry in seven mitochondrial lineages of the Southern Ocean crinoid species Promachocrinus kerguelensis (Echinodermata). Mol Ecol 21:2502-2518

Hernandez-Kantun JJ, Riosmena-Rodriguez R, Adey WH, Rind F (2014) Analysis of the cox2-3 spacer region for population diversity and taxonomic implications in rhodolith-forming species (Rhodophyta: Corallinales) Phytotaxa 190: 331-354

Hewitt GM (2000) The genetic legacy of the Quaternary ice ages. Nature 405:907-913 
Ho S, Lanfear R, Bromham, Phillips LMJ, Soubrier J, Rodrigo AG, Cooper A (2011) Timedependent rates of molecular evolution. Mol Ecol 20: 3087-3101

Hommersand MH, Fredericq S, Freshwater DW (1994) Phylogenetic systematics and biogeography of the Gigartinaceae (Gigartinales, Rhodophyta) based on sequence analysis of $r b c L$. Bot Mar 37:193-203

Hommersand MH, Fredericq S, Wilson Freshwater D, Hughey J (1999). Recent developments in the systematics of the Gigartinaceae (Gigartinales, Rhodophyta) based on $r b c \mathrm{~L}$ sequence analysis and morphological evidence. Phycol Res, 47:139-151

Hommersand MH, Fredericq S (2003) Biogeography of the marine red algae of the South African West Coast: a molecular approach. In: Chapman ARO, Anderson RJ, Vreeland VJ and Davison IR (eds) Proceedings of the XVIIth International Seaweed Symposium. Oxford University Press, Oxford, UK

Hommersand MH, Moe RL, Amsler CD, Fredericq S (2009) Notes on the systematics and biogeographical relationships of Antarctic and sub-Antarctic Rhodophyta with descriptions of four new genera and five new species. Bot Mar 52: 509-534

Huelsenbeck JP, Ronquist F (2001) MRBAYES: Bayesian inference of phylogeny. Bioinformatics $17: 754-755$

Hulton NRJ, Sugden DE, Payne A, Clapperton CM (1994) Glacier modeling and the climate of Patagonia during the last glacial maximum. Quat Res 42:1-19

Hulton NRJ, Purves RS, McCulloch RD, Sugden DE, Bentley MJ (2002) The Last Glacial Maximum and deglaciation in southern South America. Quat Sci Rev 21:233-241

Jakob SS, Martinez-Meyer H, Blattner FR (2009) Phylogeographic analyses and paleodistribution modeling indicate Pleistocene in situ survival of Hordeum species (Poaceae) in Southern Patagonia without genetic or spatial restriction, Mol Biol Evol 26:907-923 
661

662

663

664

665

666

667

668

669

670

671

672

673

674

675

676

677

678

679

680

681

682

683

684

685

686

Janosik AM, Mahon AR, Halanych KM (2011) Evolutionary history of Southern Ocean Odontaster sea star species (Odontasteridae; Asteroidea). Polar Biol 34: 575-586.

Jobb G, Von Haeseler A, Strimmer K (2004) TREEFINDER: a powerful graphical analysis environment for molecular phylogenetics. BMC Evol Biol 4:18

Kamiya M, Zuccarello GC, West JA (2004) Phylogeography of Calaglossa leprieurii and related species (Delesseriaceae, Rhodophyta) based on the rbcL gene sequences. Jpn J Phycol $52: 147-151$

Krabbe K, Leese F, Mayer C, Tollrian R, Held C (2010) Cryptic mitochondrial lineages in the widespread pycnogonid Colossendeis megalonyx Hoek, 1881 from Antarctic and Subantarctic waters. Polar Biol 33:281-292

Kuhner MK (2006) LAMARC 2.0: maximum likelihood and Bayesian estimation of population parameters. Bioinformatics 22:768-770

Kussakin OG (1973) Peculiarities of the geographical and vertical distribution of marine isopods and the problem of deep-sea fauna origin. Mar Biol 23:19-34

Lawver LA, Gahagan LM (1998) Opening of Drake Passage and its impact on Cenozoic ocean circulation. Oxford Monographs on Geology and Geophysics 39:212-226

Linse K, Griffiths HJ, Barnes DKA, Clarke A (2006) Biodiversity and biogeography of Antarctic and sub-Antarctic mollusca. Deep-Sea Res II 53:985-1008

Mahon AR, Thornhill DJ, Norenburg JL, Halanych KM (2010) DNA uncovers Antarctic nemertean biodiversity and exposes a decades-old cold case of asymmetric inventory. Polar Biol 33:193-202

McCarthy C (1997) Chromas v1.4 computer package. Griffith University, Australia

Mclvor L, Maggs CA, Provan J, Stanhope MJ (2001) rbcL sequences reveal multiple cryptic introductions of the Japanese red alga Polysiphonia harveyi. Mol Ecol 10:911-919

Moffat C, Beardsley RC, Owen B, van Lipzig N (2008) A first description of the Antarctic Peninsula Coastal Current. Deep-Sea Res II 55:277-293 
Montecinos A, Broitman BR, Faugeron S, Haye PA, Tellier F, Guillemin ML (2012) Species replacement along a linear coastal habitat: phylogeography and speciation in the red alga Mazzaella laminarioides along the south east pacific. BMC Evol Biol 12:17

Nei M, Li WH (1979) Mathematical model for studying genetic variation in terms of restriction endonucleases. Proc Natl Acad Sci USA 76:5260-5273

Nei M (1987) Molecular Evolutionary Genetics. Columbia University Press, New York, USA

Nikula R, Fraser Cl, Spencer HG, Waters JM (2010) Circumpolar dispersal by rafting in two subantarctic kelp-dwelling crustaceans Mar Ecol Prog Ser 405:221-230

Piriz ML (1996) Phenology of a Gigartina skottsbergii Setchell et Gardner population in Chubut Province (Argentina). Bot Mar 39: 311-316

Posada D, Crandall KA (1998) MODELTEST; testing the model of DNA substitution. Bioinformatics Application Note 14:817-818

Poulin E, González-Wevar C, Diaz A, Gerard K, Hune M (2014) Divergence between Antarctic and South American marine invertebrates: What molecular biology tells us about Scotia Arc geodynamics and the intensification of the Antarctic Circumpolar Current. Global Planet Change 123:392-399

Provan J, Bennett KD (2008) Phylogeographic insights into cryptic glacial refugia. Trends Ecol Evol 23:564-571

Ramirez ME, Santelices B (1991) Catalogo de algas marinas bentónicas de la costa temperada del Pacífico de Sudamérica. Monogr Biol 5:247-52

Raupach MJ, Thatje S, Dambach J, Rehm P, Misof B, Leese F (2010) Genetic homogeneity and circum-Antarctic distribution of two benthic shrimp species of the Southern Ocean, Chorismus antarcticus and Nematocarcinus lanceopes. Mar Biol 157:1783-1797

Roger AR, Harpending H (1992) Population growth makes waves in the distribution of pairwise genetic differences. Mol Biol Evol 9:552-569 
Rogers AD, Murphy EJ, Johnston NM, Clarke A (2007) Introduction. Antarctic ecology: from genes to ecosystems. Part 2. Evolution, diversity and functional ecology. Phil Trans R Soc B 362: 2187-2189

Santelices B (1988) Algas marínas de Chile. Distribución, ecología, utilización y diversidad. Ediciones Universidad Católica de Chile, Santiago, Chile

Stupnikova AN, Molodtsova TN, Mugue NS, Neretina TV (2013) Genetic variability of the Metridia lucens complex (Copepoda) in the Southern Ocean. J Mar Syst 128:175-184

Tajima F (1989) Statistical method for testing the neutral mutation hypothesis by DNA polymorphism. Genetics 123:585-595

Tamura K, Peterson D, Peterson N, Stecher G, Nei M, Kumar S (2011) MEGA5: Molecular Evolutionary Genetics Analysis Using Maximum Likelihood, Evolutionary Distance, and Maximum Parsimony Methods. Mol Biol Evol 28: 2731-2739

Tavares M, de Melo GAS. (2004) Discovery of the first known benthic invasive species in the Southern Ocean: the North Atlantic spider crab Hyas araneus found in the Antarctic Peninsula. Antarct Sci 16:129-131

Thatje S, Fuentes V (2003) First record of anomuran and brachyuran larvae (Crustacea: Decapoda) from Antarctic waters. Polar Biol 26:279-282

Thatje S, Hillenbrand C-D, Larter R (2005) On the origin of Antarctic marine benthic community structure. Trends Ecol Evol 20:534-540

Thatje S, Hillenbrand CD, Mackensen A, Larter R (2008) Life hung by a thread: endurance of Antarctic fauna in glacial periods. Ecology 89:682-692

Thorpe SE, Heywood KJ, Stevens DP, Brandon MA (2004) Tracking passive drifters in a high resolution ocean model: implications for interannual variability of larval krill transport to South Georgia. Deep-Sea Res I 51:909-920

Valdovinos C, Navarrete SA, Marquet PA (2003) Mollusk species diversity in the Southeastern Pacific: why are there more species towards the pole? Ecography 26:139-144 
Vianna JA, Medina-Vogel G, Chehebar C, Sielfeld W, Olavarria C, Faugeron S (2011) Phylogeography of the Patagonian otter Lontra provocax: adaptive divergence to marine habitat or signature of southern glacial refugia? BMC Evol Biol 11:12

Weis A, Meyer R, Dietz L, Domel JS, Leese F and Melzer, RR (2014) Pallenopsis patagonica (Hoek, 1881) - a species complex revealed by morphology and DNA barcoding, with description of a new species of Pallenopsis Wilson, 1881. Zool J Linn Soc 170:110-131

Westermeier R, Aguilar A, Sigel J, Quintanilla J, Morales J (1999) Biological basis for the

Wulff A, Iken K, Quartino ML, Al-Handal A, Wiencke C, Clayton MN (2009) Biodiversity, biogeography and zonation of marine benthic micro- and macroalgae in the Arctic and Antarctic. Bot Mar 52:491-507

Zemlak TS, Walde SJ, Habit EM, Ruzzante DE (2011) Climate-induced changes to the ancestral population size of two Patagonian galaxiids: the influence of glacial cycling. Mol Ecol $20: 5280-5294$

Zuccarello GC, Burger G, West JA, King ARJ (1999) A mitochondrial marker for red algal intraspecific relationships. Mol Ecol 8:1443-1447 
1 Deep genetic divergence between austral populations of the red alga Gigartina skottsbergii

2 reveals a cryptic species endemic to the Antarctic continent.

3

4 Emmanuelle Billard ${ }^{2}$, Jeanette Reyes ${ }^{1}$, Andres Mansilla ${ }^{3}$, Sylvain Faugeron ${ }^{4,5}$ \& Marie-Laure 5 Guillemin ${ }^{1,5}$.

6

$7 \quad{ }^{1}$ Instituto de Ciencias Ambientales y Evolutivas, Universidad Austral de Chile, Valdivia, Chile.

8 2Univ Porto, CIBIO InBIO, Ctr Invest Biodiversidade \& Recursos Genet, P-4485668 Vairao, 9 Portugal

10 '3aboratorio de Macroalgas Antárticas y Subantárticas and Instituto de Ecología y 11 Biodiversidad (IEB), Universidad de Magallanes, Chile.

$12{ }^{4}$ Centro de Conservación Marina and CeBiB, Facultad de Ciencias Biológicas, Pontificia 13 Universidad Católica de Chile, Santiago, Chile.

$14{ }^{5}$ UMI 3614 Evolutionary Biology and Ecology of Algae, CNRS, Sorbonne Universités UPMC Univ.

Paris 06, Pontificia Universidad Católica de Chile, Universidad Austral de Chile

17 Email: marielaure.guillemin@gmail.com 
21 The almost complete isolation of Antarctica after the intensification the Antarctic Circumpolar

22 Current (ACC) during the middle-Miocene has been challenged by recent molecular data 23 showing the existence of allelic exchange across the ACC. For organisms present on both sides

24 of the ACC, two hypotheses have then been discussed to explain the origin of the Antarctic 25 populations: 1) they correspond to recent immigrants from adjacent continents or 2) they have 26 evolved in situ and have survived the dramatic effects of the last Quaternary glaciations in this 27 region. The red algae Gigartina skottsbergii presents a disjoint distribution and is reported in 28 both Antarctica and southern South America, a distribution pattern that largely exceeds its dispersal capacity. Mitochondrial sequences of the intergenic region cox2-3 $(n=233)$ and partial chloroplastic RuBisCo large subunit gene $(n=26)$ sequences were obtained for individuals from the Chilean sub-Antarctic ecoregion and Antarctic Peninsula localities. The results strongly support the persistence of populations on each side of the Drake Passage during glacial periods and the existence of dispersal barrier due to the ACC. On both sides of the ACC, the last Quaternary glaciations have induced strong bottlenecks that were followed by rapid colonization events. 
Introduction

44 al. 2005).

The Southern Ocean is characterized by high levels of endemism of its fauna and flora (Clarke and Crame 1989; Brandt et al 1999; Clarke and Johnston 2003; Wulff et al. 2009) that has been related to the progressive isolation of the continent during the Mesozoic and the reinforcement of the Antarctic Circumpolar Current (ACC) during the mid-Miocene (Lawver and Gahagan 1998; Rogers et al. 2007; Poulin et al. 2014). Moreover, after the onset of icehouse conditions in Antarctic, both the radiation of groups that have adapted to this extreme environment and allopatric speciation driven by population fragmentation in Antarctic refugia during glacial period seem to have contributed to the high Antarctic diversity (Rogers et al. 2007; Thatje et al. 2008). Recent molecular data for several marine invertebrate taxa, especially those with strong dispersal capabilities, have shown that divergence between Antarctic and South American populations or sister species could be much more recent than the physical separation of the continental landmasses and may rather have been driven by more recent geographic and oceanographic changes like the evolution of the Scotia Arc and the deepening of the Drake Passage (González-Wevar et al. 2012a; Poulin et al. 2014). The ACC is generally considered to act as an impervious hydrographic barrier for most marine species (Clarke et al. 2005; Thatje et al. 2005). Indeed, many studies have shown the absence of gene flow between lineages across the ACC (Krabbe et al. 2010; Janosik et al. 2011; Stupnikova et al. 2013; Poulin et al. 2014; Weis et al. 2014). However, the permeability of this barrier has been questioned by recent studies since low levels of exchanges across the ACC have been observed for spider crabs (Clarke et al. 2005), ribbon worms (Mahon et al. 2010) and the sea star Odontaster meridionalis (Janosik et al. 2011). These new evidences of the ability of species to permeate the Polar Front have raised questions about the importance of historical land mass connectivity versus more recent exchanges across the ACC in driving the distribution of the Southern Ocean benthic biota (Thatje and Fuentes 2003; Tavares and De Melo 2004; Clarke et 

particularly puzzling when considering the major Quaternary climatic oscillations, which led to the formation of an ice-sheet reaching the limits of the continental plateau and likely eradicating life in shallow subtidal areas (Thatje et al. 2005). Many invertebrates are highly abundant and diverse along the Antarctic coasts (Clarke and Crame 1989; Clarke and Johnston 2003; Linse et al. 2006; Aronson et al. 2007; Rogers et al. 2007), suggesting that major climatic and oceanographic changes in the region did not impede their evolutionary success (Clarke and Crame 1989; Aronson et al. 2007). Several hypotheses have been proposed to explain the occurrence of such diversity despite major changes in habitat availability. The "deep-sea refugia" model proposes that species of the Antarctic shelf shifted their bathymetric range toward the deep_sea during events of maximum ice cover, and later recolonized shelf areas following the deglaciation process (Kussakin 1973; Thatje et al. 2005; Allcock and Strugnell 2012). This hypothesis has been proposed for invertebrate species with wide eurybathic ranges, and has been confirmed by phylogeographic analyses (e.g. the crinoid Promachocrinus kerguelensis; Hemery et al. 2012). However, the model is not applicable to shallow benthic species, such as seaweeds and herbivores that feed on them, due to their dependence on light availability. Two alternative hypotheses, the "shelf in situ refugia" and the "island refugia" models, propose that some species might have survived in situ either because ice did not cover the entire shelf area at the same time, or alternatively because organisms sought refuge outside of the Antarctic continental shelf in more or less distantly surrounding islands (Thatje et al. 2005; Raupach et al 2010; Diaz et al. 2012; González-Wevar et al. 2013).

In parallel, sub-Antarctic species have also experienced important changes in their respective distribution ranges due to Quaternary glacial cycles. During the Last Glacial Maximum (LGM), the southern tip of South America was covered by the Patagonian ice-sheet that extended approximately from Chiloé Island $\left(42^{\circ} \mathrm{S}\right)$ to the Fuegian low lands $\left(56^{\circ} \mathrm{S}\right)$ (Hulton et al. 2002), and this had various effects on species of southern Chile and Argentina 
(Valdovinos et al. 2003; Aguirre et al. 2013). However, coastal ice-sheets were absent in the Cape Horn region and along the Scotia Arc (Hulton et al. 1994, 2002; Fraser et al. 2012); this likely offered glacial refugia for marine species. Contrasting postglacial recolonization pathways have been inferred from the genetic evidence of several Patagonian species (González-Wevar et al. 2012a). Similarly, several terrestrial species including amphibians, river fish, mammals and plants were restricted to glacial refugia or became locally extinct, whereas others persisted in situ (i.e. in the areas putatively covered by ice-sheets; Jakob et al. 2009; Vianna et al. 2011; Zemlak et al. 2011; Fraser et al. 2012). To date few studies have focused on marine Patagonian species and the existing results indicated diverse scenarios. These scenarios include potential post-glacial recolonization from distant Sub-Antarctic sources (e.g. Durvillaea antarctica, Fraser et al. 2010), from northern, unglaciated regions (e.g. Mazzaella laminarioides, Montecinos et al. 2012), or from local refugia in the southern sub-Antarctic region (Valdovinos et al. 2003). The potential occurrence of glacial refugia between Cape Horn and the South Sandwich archipelagos raises questions about the origin of both sub-Antarctic and Antarctic diversity.

With its present distribution embracing the southern coast (up to $40^{\circ} \mathrm{S}$ ) of Chile and Argentina, sub Antarctic islands (Falkland Islands), Antarctic Islands (South Shetland, South Orkney Islands and South Georgia) and the Antarctic Peninsula, the red alga Gigartina skottsbergii is a suitable model to investigate the impact of major climatic changes on the subtidal flora in high southern latitudes. This species is highly patchy, with populations generally less than a square kilometer in size (Ramirez and Santelices 1991). It belongs to the order Gigartinales, which appears to have originated on Antarctic coasts when this continent was still attached to Australasia and South America (Hommersand et al. 1994). The northern limit of G. skottsbergii's distribution is set by contrasting topological and oceanic characteristics including changes in the seawater surface temperature (i.e. the transition 
121 carraghenophyte alga is pseudo-perennial (Wiencke and Clayton 2002) and blades may reach

122 up to 1-2m in diameter (Santelices 1988). G. skottsbergii is haploid-diploid and both phases of 123 the isomorphic life cycle coexist in time and space (Piriz 1996; Avila et al. 1999; Westermeier et 124 al. 1999). Propagation is achieved through sexual reproduction (Avila et al. 1999). Antarctic specimens are separated from South American plants by more than $2 \%$ rbcL base pair distance (Hommersand and Fredericq 2003), which is not uncommon among species within red algae (e.g. Gavio and Fredericq 2002). Furthermore, Antarctic and sub-Antarctic populations show physiological differences: while in Antarctica spores germinate at $0^{\circ} \mathrm{C}$ and juveniles grow only at temperatures below $5^{\circ} \mathrm{C}$ (Bischoff-Bäsmann and Wiencke 1996), spores from sub-Antarctic populations do not germinate at $0^{\circ} \mathrm{C}$ and can grow at up to $15^{\circ} \mathrm{C}$ (Buschmann et al. 1999) which might result from an adaptation to regional environmental conditions. These first genetic and physiological results suggest that there is some evolutionary divergence between Gigartina populations from Antarctica and South America. The objective of this study is to infer the evolutionary history of sub-Antarctic and Antarctic populations of the red alga $G$. skottsbergii (Setchell et Gardner) using mitochondrial and chloroplast markers Cox2-3 and rbcL. Two main processes were investigated: the divergence between Antarctic and South American populations, and the genetic consequences of last glacial cycle on both continents.

Materials and Methods.

Sampling-Samples were collected by autonomous diving in the shallow subtidal zones and includes a total of 233 individuals of G. skottsbergii. Samples were extracted from 18 localities covering most of the distribution range of the species (Chilean and Antarctic coasts;

143 Table 1). In order to avoid sampling genetically identical ramets we sampled fronds from 144 distinct holdfasts. Individuals were sampled from the lower littoral down to the depth of $25 \mathrm{~m}$. 
Each individual tissue sample was cut from a clean healthy frond and placed into a plastic bag filled with silica beds for rapid dehydration and preservation of DNA. DNA extraction, PCR amplification and sequencing- Dried algal tissue was finely grounded using liquid nitrogen and DNA was extracted using the phenol-chloroform method described in Faugeron et al. (2001). The Cox2-3, an intergenic non-coding mitochondrial region located between the genes for cytochrome oxidase subunit 2 (COX2) and 3 (COX3) was amplified following Zuccarello et al. (1999). In total, 233 sequences of approximately $350 \mathrm{bp}$ were obtained. Additionally, we amplified a $971 \mathrm{bp}$ region of the chloroplastic gene $r b c \mathrm{~L}$, encoding the large subunit of the ribulose-1,5-bisphosphate carboxylase/oxygenase (RUBISCO) enzyme, using the primers F-rbcL and R-rbcL (Hommersand et al. 1994) and the PCR conditions described by Fredericq and Lopez-Bautista (2002). Sequences were obtained for a sub-sample of 26 individuals (Table 1) for the $r b c L$ gene. All PCR reactions were performed in a Gene Amp PCR system 9700 (Applied Biosystems, Foster City, USA). The amplified samples from each individual were purified with the UltraCleanTM kit (MO BIO Laboratories, Carlsbad, USA) and sequenced in both directions by Macrogen Inc. (Seoul, South Korea). Sequences were edited using Chromas v. 2.33 (McCarthy 1997) and alignments were obtained using the CLUSTAL function of Mega v 5 (Tamura et al. 2011). Sequences were deposited in Genbank with accession numbers KM261841 to KM261858 for the Cox2-3 region and accession numbers KM261859 to KM261862 for the $r b c L$ region. Alignments of the sequences used for the Cox2-3 region and the $r b c L$ for phylogenetic reconstructions are available in Online Resources 1 and 2, respectively.

For the $r b c L$ and the coding part of the Cox2-3 sequences obtained, the McDonaldKreitman test (http://mkt.uab.es, Egea et al. 2008) was performed to detect selection. The neutrality index (NI) was calculated as follows: $\mathrm{NI}=(\mathrm{Pn} / \mathrm{Ps}) /(\mathrm{Dn} / \mathrm{Ds})$, where $\mathrm{P}$ is the polymorphism within the population, $D$ is the divergence or fixed difference between populations, $\mathrm{n}$ is for non synonymous and $\mathrm{s}$ is for synonymous mutations. 
172 reconstructions for each marker dataset were performed with the Maximum Likelihood (ML)

173 method using TreeFinder v March 2011 (Jobb et al. 2004) and a Bayesian inference (BI) using

174 MrBayes v 3.1.2 (Huelsenbeck and Ronquist 2001). Outgroup species belonging to the genus

175 Sarcothalia and Iridaea were chosen since they represent the closest known sister-taxa of

176 Gigartina skottsbergii in the phylogenetic systematics of the Gigartinaceae (Hommersand et al.

177 1999). Outgroup sequences considered for the $r b c L$ consisted of four species of Sarcothalia (S. and two sequences of Iridaea cordata from Antarctica (U02989 and GQ323780). For the cox23, two sequences of S. crispata (KM275591 and KM275592, both from Punta Estaquilla) and one sequence of I. cordata (KM275593 from Punta Hanna, South Shetland Islands) were used as outgroup. We also included in the analyses available $r b c L$ sequences for $G$. skottsbergii (U03432, Ancud, Chile and AF146206, King George Island, South Shetland Islands; Hommersand et al. 1999). For both phylogenetic reconstruction methods, large indels within the non-coding intergenic region of the Cox2-3 were treated as single mutation events. $M L$ analyses were performed using a mixed model taking into account the position of codons for the $r b c \mathrm{~L}$ gene while only one model was used for the cox2-3 intergenic region analysis. TreeFinder v March 2011 (Jobb et al. 2004) allows to choose between 32 substitution models for each partition of the data set. The best-fitted substitution models were selected using the Akaike Information Criterion implemented in the ModelTest package of the TreeFinder program (Posada and Crandall 1998; Jobb et al. 2004). The selected models for the $r b c \mathrm{~L}$ data were $\mathrm{TN}+\mathrm{G}$ for the first codon position, $\mathrm{HKY}+\mathrm{G}$ for the second codon position and $J 3+G$ for the third codon position. For cox2-3 the selected model was $H K Y+G$. Using TreeFinder v March 2011, we performed a heuristic search in order to reconstruct the trees and node supports were assessed by non-parametric bootstrapping (1000 pseudo-replicates, Felsenstein 1985). 

parameters defined for each dataset. Four independent analyses were run with four chains each ( 3 heated chains and one "cold" chain) for ten million generations. The settings were a heating parameter value of 0.2 and sampling every 1000 generations with randomly generated starting trees. The first $25 \%$ of sampled trees were discarded as "burn-in" to ensure convergence. The remaining trees were used to compute a consensus topology and posterior probability values. The split frequency (variance between the four independent runs) was below 0.0005 , confirming that the posterior probability distribution was accurately sampled. Because the posterior probability bootstrap values were essentially identical in the independent runs starting from different, random topologies, we considered that the chains had converged.

Even though the lack of fossils impedes a precise calibration of molecular clocks in red algae, we used divergence rates already published for this group to estimate the historical divergence event between South American and Antarctic populations. A divergence rate of 0.109-0.127\% per site per million years (Myr) has been proposed for $r b c L$ (Kamiya et al. 2004). For cox2-3, a site mutation rate of $0.756-0.426 \%$ per Myr, based on the divergence of the red algae Asparagopsis spp. associated to the Panama isthmus closure, was proposed by Andreakis et al. (2007). Divergence time was estimated in BEAST v1.8 (Drummond et al. 2012) using the Yule model of tree prior, a gamma site heterogeneity model to allow variation among sites of the mutation rate, and a Log-normal relaxed clock with a uniform sampling within the range of published mutation rates. Four runs of ten millions MCMC iterations each were performed and the combined results were analyzed with Tracer v1.8 (Drummond et al. 2012). Effective sample size of the posterior distribution, the parameter of accuracy of the parameter estimation, was always superior to 300 in each individual run and in the combined analyses, indicating the MCMC appropriately converged to estimated values. 
223 location and for the two phylogenetic lineages (i.e. G. skottsbergii from Chile and the Falkland

224 Islands and G. skottsbergii from sub-Antarctic and Antarctic) using Arlequin v 3.5 (Excoffier and Lisher 2010): the number of haplotypes $(\mathrm{nH})$; the number of private haplotypes (i.e. haplotypes found in a single population, nHpriv); the number of polymorphic sites (S); gene diversity (Hd, Nei 1987) and nucleotide diversity ( $\pi$, Nei and Li 1979). For $r b c$, only nH was calculated. reconstructed for cox2-3 using the median-joining algorithm implemented in NETWORK $v$ 4.510 (Bandelt et al. 1999). Moreover, for this molecular marker, three complementary approaches were used to infer the historical demography of G. skottsbergii from Chile and the Falkland Islands. First, Tajima's D (Tajima 1989) and Fu's Fs (Fu 1997) statistics were calculated to detect significant past changes in population size. Significant departure from mutation-drift equilibrium was tested by 1000 bootstrap replicates in Arlequin (Excoffier and Lisher 2010). Under the assumption of neutrality, negative values characterize populations in expansion while positive values, associated with the loss of rare haplotypes, are considered as a signature of recent bottlenecks (Tajima 1989, Fu 1997). Second, the observed distributions of pairwise differences were compared to estimated values under a model of sudden pure demographic expansion (Roger and Harpending 1992) using Arlequin (Excoffier and Lisher 2010). The model fit between the observed and estimated mismatch distributions was calculated through a generalized least squares approach, which was then tested with 1000 permutations. The date of growth/decline $245(\tau=2 \mu \mathrm{t})$, measured in units of $1 / 2 \mu$ generations where $t=$ time in years and $\mu=$ mutation rate per sequence per generation, was estimated using the demographic expansion parameters as 
determined in the nonlinear least squares approach implemented in Arlequin (Excoffier and Lisher 2010).

Third, population growth rate and timing was estimated from coalescent simulations implemented in LAMARC 2.1.9 (Kuhner 2006). The maximum likelihood approach was applied using the Metropolis-coupled Markov chain Monte Carlo (MCMC) method with replication of chains and adaptive heating to achieve optimal sampling of the parameter space. The MCMC runs were performed three times with random seeds; each run used 10 initial chains with 500 samples and two long final chains with 10000 samples. All initial chains and final chains were simulated using a sampling interval of 20 and a burn-in of 1000 samples. A tenfold evolutionary rate (4.26-7.56\% per million years) was considered at population level, following the correction for time dependence of molecular rate proposed by Ho et al. (2011).

Results.

Four chlorotypes were detected for the chloroplast marker $r b c \mathrm{~L}$, with 23 polymorphic sites along the 971 base pair fragments sequenced (11 sequenced individuals, Table 1 ). For the cox2-3 mitochondrial marker, 18 mitotypes were observed (233 sequenced individuals, Table 1). For this marker, 48 polymorphic sites were observed including two indels: one indel of $1 \mathrm{bp}$ characteristic of the mitotype $\mathrm{C} 13$ and one indel of $12 \mathrm{bp}$ for mitotypes $\mathrm{C} 8$ and $\mathrm{C} 17$. Sequence length of cox2-3 sequences varied from 337 to $350 \mathrm{bp}$.

Figure 1 shows the Maximum Likelihood (ML) phylogenetic trees constructed using the two molecular markers. For both markers, tree topologies based on Bayesian and ML analyses were largely congruent and shared comparable support values for major nodes (Figure 1). Regardless of the marker used, tree topologies were broadly similar among phylogenetic reconstruction methods and clearly showed that all G. skottsbergii sequences obtained in this 
support values $>89 \%$ ) that are strongly divergent from the outgroup species. The first lineage is

273 composed of all individuals from Chile and the Falkland Islands while the second is composed

274 of individuals from the Antarctic Peninsula, the South Shetland Islands and the South Orkney Islands (Figure 1). The available rbcL sequence AF146206 in GenBank for G. skottsbergii previously sampled in King George Island in the South Shetland Islands (Hommersand et al. 1999) corresponds exactly to the chlorotype R4 present in our Antarctic lineage. The uncorrected p-distance, measured using only 665bp, between the $r b c L$ sequence U03432 and the closest sequence in our data set (i.e. chlorotype R1, present only in Ancud, Chile, see Table 1 ) is of $0.3 \%$. This is congruent with the location where the specimen corresponding to the U03432 sequence was collected, on Chiloé Island within the bay of Ancud (Hommersand et al. 1999). P distances between sequences from the Antarctic and South American G. skottsbergii lineages were of $9.2 \pm 1.5 \%$ for cox $2-3$ and of $2.1 \pm 0.5 \%$ for $r b c L$. When performed between the Antarctic and South American G. skottsbergii lineages, no significant departure from neutrality was detected using the McDonald-Kreitman test for the $r b c L$ and the coding part of Cox2-3, respectively). estimated at 9.4 Myr (95\% Cl: 3.2-16.4Myr) based on cox2-3 data and at $14.9 \mathrm{Myr}$ (95\% Cl: 2.635.9Myr) based on $r b c L$ data.

For both markers, no genetic diversity was observed in the Antarctic lineage of $G$. skottsbergii. Only one haplotype was detected for the cox2-3 region and for the $r b c \mathrm{~L}$ gene, the mitotype C18 and the chlorotype R4, respectively (Table 1). The Antarctic lineage is spread over more than $1600 \mathrm{~km}$ of coast, from Marguerite Bay (67 $\mathrm{S})$ to the South Orkney Islands $\left(60^{\circ} \mathrm{S}\right)$ (Table 1, Figure $\left.2 \mathrm{C}\right)$. Within the South American lineage of G. skottsbergii the genetic diversity in cox2-3 was generally low with the number of mitotypes per sampling site $(\mathrm{nH})$ 

populations (Table 1). The highest genetic diversity was observed in the population of PAG, $\mathrm{BCH}$ and $\mathrm{FAL}(\mathrm{nH}=5$ and $\mathrm{Hd}>0.5$ in all three populations, Table 1). These three populations were also the ones with the highest number of private haplotypes, with three private haplotypes in PAG and FAL and two in BCH (Table 1). For the $r b c \mathrm{~L}$ gene, only three chlorotypes were observed within the South American lineage of G. skottsbergii. Only one chlorotype was found in each single population and the only private chlorotype (R1) was observed in the ANC population (Table 1). The chlorotype R3 was shared between BOR in Tierra del Fuego and FAL located in the Falkland Islands (Table 1).

The cox2-3 mitotype network revealed the presence of two main haplogroups, one for South America and one for Antarctica, which are separated by 31 bp (Figure 2A), a result fully congruent with the phylogenetic reconstructions (Figure 1). Within the South American haplogroup, characterized by a typical star-like topology, pairs of mitotypes were separated by 1 to $5 \mathrm{bp}$, except for the mitotypes $\mathrm{C} 17$ and $\mathrm{C} 8$ that were differentiated by a unique $12 \mathrm{bp}$ indel. This haplogroup is also characterized by one frequent and widespread mitotype (C1, 81\% of the samples, Table 1) and several less frequent mitotypes (Figure 2A). Low frequency mitotypes were predominantly restricted to a single or few nearby local populations. For example, the mitotype C3 was observed in BLO and PAG, these being two populations located in the Moraleda Channel. Additionally, mitotype $\mathrm{C} 7$ was observed in $\mathrm{BCH}, \mathrm{BOR}$ and TOR which are located in the southern part of the Magellanic region and Tierra del Fuego (Figure 2B). One mitotype, $\mathrm{C} 13$, was also shared between $\mathrm{BCH}$ in the southern part of the Magellanic region and FAL located in the Falkland Islands (Figure 2B). As expected, the star-like topology is coupled with a unimodal mismatch distribution (Figure $3 \mathrm{~A}$ ), and the values of Tajima's $D$ and Fu's Fs statistics were both negative and significant $\left(D=-2.01, p=0.001 ; F_{s}=-1.26, p=0.0001\right) a$ result congruent with a sudden demographic population expansion model. Population size changes depicted from the mismatch distribution was $\tau=0.73$ (90\% confidence interval of 0.00 
to 2.23). Assuming the start of exponential demographic expansion when population size was

$3241 \%$ of present-day's estimate, it was estimated to initiate $20000-36000$ years before present.

325 A large positive exponential growth rate, $g=3004$ (2458-4666 95\% confidence interval), was

326 also detected. It is possible that demographic expansion led to a large increase in $\mathrm{Ne}$

327 (approximately 170000 to 300000 -fold increase, Fig. 3B), which may have started during or

328 just before the LGM, depending on the combination of growth and mutation rates considered

329 within their respective confidence limits.

Discussion

332 The patterns of genetic structure for G. skottsbergii seem to confirm the absence of gene flow between Antarctic and South American populations. Regardless of the marker analyzed, phylogenetic reconstructions using mtDNA and cpDNA sequences showed strong congruence and clear support for two distinct lineages consisting of populations from South America and the Falklands on the one hand and populations from the Antarctic Peninsula, Shetlands and Orkney Islands on the other hand. The absence of shared haplotypes between the two regions may reflect the isolation created by the Antarctic Circumpolar Current between the Antarctic Peninsula and the South American continent. Divergences among lineages of G. skottsbergii for the Cox2-3 $(9.2 \pm 1.5 \%)$ and for the $r b c \mathrm{~L}(2.1 \pm 0.5 \%)$ are within the range reported for interspecific distances between sister species in Rhodophyta (ranging from $2.55 \%$ to $4.70 \%$ and from $0.77 \%$ to $5.08 \%$ for the Cox $2-3$ and the $r b c L$, respectively; Mclvor et al. 2001; Destombe et al. 2010; Hernández-Kantún et al. 2014). The large range estimated, of 2.6 to 35.9 My depending on the genetic marker and the mutation rate considered (with central tendency around 9 to $15 \mathrm{My})$, for divergence time between the two lineages seems to predate Pleistocene glaciations. This time of divergence is however more recent than the separation of the Antarctic continent from the South American continent (approximately 24-40 Myr ago), 
and seems to include the period of intensification of the ACC circulation 11-12 Myr ago (Dalziel et al. 2013). These climatic and oceanographic changes have been shown to be major drivers in the isolation of marine Antarctic fauna. For example, González-Wevar et al. (2010) have shown that the diversification within a genus of mollusk (Nacella) took place long after the separation of the continents. For these marine mollusks, the appearance of the most genetically distant clades (Kerguelen, Antarctic, and South America) took place between 9 and 5 Myr. These results were further supported by a recent study of comparative phylogeography of different invertebrate taxa showing a shared Antarctic and South American distribution (GonzálezWevar et al. 2012a; Poulin et al. 2014). In these studies, divergence times between Antarctic and South American lineages ranged from 1.0 to $13.6 \mathrm{Myr}$, largely overlapping the estimates for G. skottsbergii. Interestingly, divergence estimates in the mitochondrial markers for $G$. skottsbergii (9.2\%) fall within the $7-11 \%$ range for shallow subtidal and intertidal invertebrates (González-Wevar et al. 2010, 2012a; Poulin et al. 2014), corroborating the occurrence of a shared evolutionary history despite imprecisions in the respective mutation rates. These authors proposed that the connection between Antarctic and South American populations could have been maintained by a stepping stone process along the archipelago of the Scotia Arc. Indeed, geological evidence has recently been reported of a now-submerged volcanic arc in the Central Scotia Sea that existed during the early Miocene (Dalziel et al. 2013). This archipelago was located closer to the Antarctic Peninsula and the Cape Horn region than the South Sandwich Islands are today, and may thus have provided a corridor for genetic connectivity across the Drake Passage until approximately 10-11 Myr ago (Poulin et al. 2014). Our study further shows that G. skottsbergii, a seaweed characterized by a very restricted dispersal capacity of its spores, may also have maintained a certain level of connectivity (even after the mid-Miocene) between the continents of Antarctica and South America through the volcanic arc of islands linking both sides of the Scotia Sea. This connection could have been 
374 invertebrates, through rafting of adults (Nikula et al. 2010; Haye et al. 2012; Poulin et al. 2014).

375 The Antarctic and South American lineages of G. skottsbergii exhibit different patterns of genetic diversity. While a strong demographic expansion was inferred in the sub-Antarctic region, a total absence of genetic diversity was observed in the Antarctic lineage. The presence of a single haplotype over more than $1600 \mathrm{~km}$ from Marguerite Bay to the South Orkney Islands is intriguing. Even if this lack of diversity limits our capacity to test for different demographic scenarios in Antarctica, it suggests that a very strong demographic bottleneck occurred during glacial contraction, followed by a sudden and recent recolonization process that did not allow for new mutations. Similarly, the overall low genetic diversity and the presence of the same common haplotype C1 in every population from the Chilean coast to the Falkland Islands seems to support the hypothesis of persistence in a single glacial refugium followed by a massive demographic expansion over $2500 \mathrm{~km}$. Such a pattern of genetic homogeneity over a broad geographical range has usually been related to high dispersal potential (Bortolotto et al. 2011; González-Wevar et al. 2012b). The scenario of rapid recolonization leading to the presence of only one haplotype over thousands of kilometers of coast is, however, difficult to envision for G. skottsbergii. Indeed, this alga is a non-buoyant species, and spore dispersal is considered to be very limited (Ramirez and Santelices 1991). Nevertheless, signatures of long distance dispersal have been observed in other apparently non-dispersive algal species like Adenocystis utricularis or Bostrychia intricata and have been explained by the organisms' potential ability to raft on floating substrates (Fraser et al. 2010, 2013). In contrast with our results, in a previous study using RAPDs nuclear markers (Faugeron et al. 2004), significant genetic differentiation among South American populations was observed and has been related to the poor dispersal capacity of for G. skottsbergii. Differences in mutation rates and/or level of drift effects (effective population size of uniparentally inherited loci is only one-fourth that of nuclear loci) may account for the differences between 
level of genetic structure obtained with RAPDs (Faugeron et al. 2004) and cytoplasmic

400 sequences (our study). Also, during spatial expansion, gene surfing effects may contribute to the reduction of diversity in cytoplasmic markers in the recolonized region (Excoffier and Ray 2008). Indeed, large-scale spread of mitochondrial genetic variants has been observed during recolonization process in seaweeds (Fraser et al. 2010). The ACC is a strong west to east current that connects the Antarctic Peninsula and the South Shetland Islands to the Antarctic Islands located in the South Scotia Ridge. Particle movement modeling and particle tracking has shown that passive drifters travel northeastwards across the Scotia Sea, connecting the Antarctic Peninsula and the South Shetland Islands to South Orkney Islands and South Georgia (Thorpe et al. 2004). Movement of drifting seaweed along the ACC could be connected to west-east spatial expansion pattern. On the other hand, the postglacial colonization of the Peninsula could have been promoted by stepwise spatial expansion through spore propagation. Such spatial expansion could have been facilitated by strong coastal currents, as the Antarctic Peninsula Coastal Current (APCC; Moffat et al. 2008), a southward current that

413 forms during the ice-free seasons and extends to Alexander Island. However, we lack knowledge on the actual mechanisms of dispersal in G. skottbergii to appropriately determine the role of dispersal during post-glacial population dynamics on the present day genetic diversity.

The location of both Antarctic and South American glacial refugia is difficult to infer from the results presented here. The extreme genetic homogeneity within the G. skottsbergii Antarctic clade is in disagreement with the hypothesis that genetic structure and global genetic diversity in Antarctica may have been promoted by the fragmentation and isolation of micro-refugia where marine species were able to survive during repeated ice advances and retreats (Thatje et al. 2005; Allcock and Strugnell 2012). The possible presence of micro-refugia has been particularly highlighted in the archipelagoes located near the West Antarctic Peninsula and the 
data have shown that the South Shetland Islands is the most speciose region for endemic

426 Southern Ocean octopuses of the genus Pareledone (Allcock et al. 2011). Even though the data

427 herein lack the explicit molecular diversity to test adequately for the number and location of glacial refugees in this region, the survival of $G$. skottsbergii during the LGM seems more likely in the northernmost latitude (South Shetland and South Orkney Islands). Indeed, whereas G. skottsbergii is found in dense beds within these northern archipelagos, less than ten specimens could be collected in Paradise Bay and only one specimen was sampled in Marguerite Bay (Note that the same sampling effort was applied in Paradise Bay, Marguerite Bay, O'Higgings and Punta Prat; Table 1; M-L Guillemin, personal communication). It is understood that an increased sampling effort could better elucidate the southern limits of $G$. skottsbergii, but it seems that in Marguerite Bay the alga has reached a biotic or abiotic limit to its distribution.

The absence of genetic structure for the mitochondrial and chloroplast markers in southern South America also limits our ability to infer the number and location of glacial refugia. Because of their longstanding demographic stability, populations from glacial refugia are expected to present higher levels of genetic diversity than those populations that have formed following postglacial expansions (Provan and Bennett 2008). In addition, long-term isolation in distant refugia often leads to genetic differentiation due to mutation accumulation and genetic drift (Hewitt 2000). Along the Chilean coast, recolonization pathways have differed between organisms in terms of the number and origin of sources. A recent recolonization from a single distant/exterior source has been proposed to explain the high genetic homogeneity of populations of the red alga Mazaella laminarioides (Montecinos et al. 2012) and the brown alga Durvillaea antarctica that exist south of $42^{\circ} \mathrm{S}$ (Fraser et al. 2010). In M. laminarioides, a single refugium has been proposed, located in the North of the Island of Chiloe and the mainland coast north of the $41^{\circ} \mathrm{S}$ (Montecinos et al. 2012). In D. antarctica, broad sampling across the southern hemisphere has shown that all individuals present off the Patagonian coast of Chile share the same haplotype (Fraser et al. 2010) and the authors have indicated 
451 that this species likely recolonized the region from a refugium in New Zealand sub-Antarctic

452 archipelagoes. Yet others have highlighted the role that the Southern Fjords and Channels

453 Region played as a refuge for several animal species, like marine mollusks (Valdovinos et al.

454 2003; González-Wevar et al. 2010) and the river otter (Vianna et al. 2011). The existence of

455 multiple refugia, scattered among the Southern Fjords and Channels, has been proposed to

456 explain the high levels of endemism and the high diversity of mollusks in this region

457 (Valdovinos et al. 2003). In G. skottsbergii, the overall low genetic diversity and the presence of the same common haplotype, $\mathrm{C} 1$, in every population from the Chilean coast to the Drake Passage and the Falkland Islands seem to support the hypothesis of a single glacial refugium. Strong currents (i.e. the Cape Horn Current and the Malvinas-Falkland Current) connect the southern coast of Chile from $42^{\circ} \mathrm{S}$ to Cape Horn and the Falkland Islands. These currents have been shown to provide high connectivity among all inhabiting regions for the genus Nacella

463 (González-Wevar et al. 2012b). In this genus, the existence of asymmetric gene flow, from 464 West to East, was shown to be related to the prevailing circulation patterns in this region 465 (González-Wevar et al. 2012b). Due to these strong directional currents, the hypothesis of a postglacial recolonization of the Chilean coast by G. skottsbergii from a refuge located in the Falkland Islands is most unlikely. Again, more polymorphic markers should help identifying regions with higher / lower genetic diversity as putative locations of glacial refugia / recolonized areas, respectively, for $G$. skottsbergii.

In accordance with previous results of Hommersand et al. (2009) the data presented here clearly show two divergent and respectively monophyletic clades of G. skottsbergii that may correspond to two cryptic species. G. skottsbergii (Type locality: Slogget Bay, Fuegia - Silva 
476 Chile and the Falkland Islands. The Antarctic species, still to be formally described and named,

477 occurs in the Antarctic Peninsula, the South Shetland Islands and the South Orkney Islands.

478 Despite drastic reductions in population size, as revealed by strong signals of bottlenecks, both

479 species persisted and maintained their separation on either side of the ACC even during the

480 glacial period. The divergence time between the two cryptic species, estimated as 9.4 to

481 14.9 Myr (comparable with other invertebrate species, but with a large confidence interval of

482 2.6-35.9Myr), indicates that algae with limited dispersal capabilities were able to cross the

483 Scotia Sea after separation of the continents, potentially via a stepping stone process through

484 the volcanic arc of islands. Our work also sheds light on the possible importance of dispersal by

485 rafting in the recolonization process of a species for which natural propagation is mainly

486 achieved via sexual reproduction (Avila et al. 1999; Westermeier et al. 2012). Future prospects

487 on glacial refugia for Antarctic and sub-Antarctic seaweeds shall also contribute to better

488 understand the dispersal mechanisms during demographic expansion in these regions

489 characterized by complex topography of coastal shelf and coastal currents.

490

491 Acknowledgments

492 This research was supported by the Instituto Antártico Chileno (INACH) project T_16-11. EB is

493 granted by a postdoctoral fellowship from the Project "Genomics Applied To Genetic

494 Resources" cofinanced by North Portugal Regional Operational Programme 2007/2013 (ON.2 -

495 O Novo Norte), under the National Strategic Reference Framework (NSRF), through the

496 European Regional Development Fund (ERDF). Additional support came from the International

497 Research Network "Diversity, Evolution and Biotechnology of Marine Algae" (GDRI N 0803)

498 and from the CONICYT FONDECYT/REGULAR N 1140940. The authors thank P. Brunning, J. L.

499 Kappes, T. Heran, Y. Henriquez, J. Ojeda and L. Vallejos for their help in the field and M. E.

500 Ramírez for her help in identification of vouchers from Antarctica and E. Giles for English 
501 correction. The authors would also like to thank C. González-Wevar and four anonymous

502 reviewers for their critical comments and valuable suggestions, which helped to improve this

503 manuscript. We also thank the Chilean Navy (especially the captain and crew of the ships

504 Almirante Oscar Viel and Lautaro), the staff from the Chilean Army in the O'Higgins base and

505 the Air Force of Chile (FACh) for the logistic support of our fieldwork in sub-Antarctica and 506 Antarctica.

507 
Figure 1: Maximum likelihood rooted trees for the cox2-3 and the rbcL haplotypes of Gigartina

509 skottsbergii. Maximum likelihood bootstrap values are indicated above each node and 510 Bayesian posterior probabilities are noted between brackets. Only high support values are 511 shown ( $>75$ for bootstraps and $>0.95$ for posterior values, respectively; - correspond to 512 branches not observed in the Bayesian inference reconstruction).

513 Figure 2: Haplotype networks of Gigartina skottsbergii and their geographic distribution based 514 on cox2-3. The haplotype networks are presented in (A) while the pie charts showing the 515 geographical distribution of haplotypes of the South American haplogroup are shown in (B) 516 and the pie charts showing the geographical distribution of haplotypes of the Antarctic haplogoup are shown in (C). In the networks, each circle represents a haplotype and its size is proportional to the frequency in which the haplotype was encountered (correspondence between circle sizes and numbers of individuals is indicated in the box A). The black square inbetween C7, C9 and C14 represents a hypothetical un-sampled haplotype. For haplotypes separated by more than one mutational step, the number of steps is indicated in bp. Pie charts' color-code corresponds to the one used in haplotype networks. Abbreviations for population codes are as in Table 1. Numbers of sequenced individuals are given between brackets.

Figure 3: Mismatch distributions (A) and population growth rate estimates (B) of the South American haplogroup of Gigartina skottsbergii for the cox2-3 marker. Growth rate and timing of population dynamic changes were estimated from coalescent simulations implemented in LAMARC 2.1.9 (Kuhner 2006). The observed distribution of the number of pair base differences between sequences is indicated by the grey bars while the expected distribution under a

530 model of sudden demographic expansion is represented by a black line. Effective population 531 size (i.e. Ne) fluctuations throughout time are represented in the LAMARC graph. The dotted 532 lines represent the $95 \%$ confidence intervals of the estimated growth rate, whereas the grey 
533 shaded area corresponds to the average growth rate combined with the range of mutation

534 rates proposed by Andreakis et al (2007) corrected by a tenfold evolutionary rate as suggested

535 at population level for time dependence of molecular rate by Ho et al. (2011). 
537

538

539

540

541

542

543

544

545

546

547

548

549

550

551

552

553

554

555

556

557

558

559

560

Aguirre ML, Richiano S, Donato M, Farinati EA (2013) Tegula atra (Lesson, 1830) (Mollusca, Gastropoda) in the marine Quaternary of Patagonia (Argentina, SW Atlantic): Biostratigraphical tool and palaeoclimate-palaeoceanographical signal Quatern Int 305:163-187

Allcock AL, Barratt I, Eleaume M, Linse K, Norman MD, Smith PJ, Steinke D, Stevens DW, Strugnell JM (2011) Cryptic speciation and the circumpolarity debate: A case study on endemic Southern Ocean octopuses using the COI barcode of life. Deep-Sea Res II $58: 242-249$

Allcock AL, Strugnell JM (2012) Southern Ocean diversity: new paradigms from molecular ecology. Trends Ecol Evol 27:520-528

Andreakis N, Proccacini G, Maggs C, Kooistra WHCF (2007), Phylogeography of the invasive seaweed Asparagopsis (Bonnemaisoniales, Rhodophyta) reveals cryptic diversity. Mol Ecol 16: 2285-2299

Aronson RB, Thatje S, Clarke A, Peck LS, Blake DB, Wilga CD, Siebel BA (2007) Climate change and Invasibility of the Antarctic Benthos. Annu Rev Ecol Evol Syst 38:129-154

Avila M, Candia A, Nunez M, Romo H (1999) Reproductive biology of Gigartina skottsbergii (Gigartinaceae, Rhodophyta) from Chile. Hydrobiologia 399:149-157

Bandelt HJ, Forster P, Röhl A (1999) Median-Joining networks for inferring intraspecific phylogenies. Mol Biol Evol 16:37-48

Bischoff-Bäsmann B, Wiencke C (1996) Temperature requirements for growth and survival of Antarctic Rhodophyta. J Phycol 32: 525-535

Bortolotto E, Bucklin A, Mezzavilla M, Zane L, Patarnello T (2011) Gone with the currents: lack of genetic differentiation at the circum-continental scale in the Antarctic krill Euphausia superba. BMC Genetics 12:32 
Brandt A, Linse K, Mühlenhardt-Siegel U (1999) Biogeography of Crustacea and Mollusca of the Magellan and Antarctic regions. Sci Mar 63:383-389

Buschmann AH, Correa JA, Westermeier R (1999) Recent advances in the understanding of the biological basis for Gigartina skottsbergii Rhodophyta. cultivation in Chile. Hydrobiologia 398/399: 427-434

Clarke A, Crame JA (1989) The origin of the Southern Oceanmarine fauna. In: Crame JA (Ed) Origins and evolution of the Antarctic biota. Geological Society Special Publications, vol 47. The Geological Society, London

Clarke A, Johnston NM (2003) Antarctic marine benthic diversity. Oceanogr Mar Biol Annu Rev 41:47-114

Clarke A, Barnes DKA, Hodgson DA (2005) How isolated is Antarctica? Trends Ecol Evol 20:1-3

Dalziel IWD, Lawver LA, Norton IO, Gahagan LM (2013) The Scotia Arc: genesis, evolution, global significance. Ann Rev Earth and Planetary Sciences 41:767-793

Destombe C, Valero M, Guillemin M-L (2010) Delineation of two sibling red algal species, Gracilaria gracilis and Gracilaria dura (Gracilariales, Rhodophyta), using multiple DNA markers: Resurrection of the species $G$. dura previously described in the Northern Atlantic 200 years ago. J Phycol 46:720-727

Diaz A, González-Wevar CA, Maturana C, Palma AT, Poulin E, Gerard K (2012) Restricted geographic distribution and low genetic diversity of the brooding sea urchin Abatus agassizii (Spatangoidea: Schizasteridae) in the South Shetland Islands: A bridgehead population before the spread to the northern Antarctic Peninsula? Rev Chil Hist Nat 85:457-468.

Drummond AJ, Suchard MA, Xie D \& Rambaut A (2012) Bayesian phylogenetics with BEAUti and the BEAST 1.7 Mol Biol Evol 29: 1969-1973

Excoffier E, Ray N (2008) Surfing during population expansions promotes genetic revolutions and structuration. Trends Ecol Evol 23:347-351 
587 Excoffier L, Lisher H (2010) Arlequin suite ver 3.5: A new series of programs to perform 588 population genetics analyses under Linux and Windows. Mol Ecol Resour, 10:56

589 Faugeron S, Valero M, Destombe C, Martínez EA, Correa JA (2001) Hierarchical spatial 590 structure and discriminant analysis of genetic diversity in the red alga Mazzaella

Faugeron S, Martinez EA, Correa JA, Cardenas L (2004) Reduced genetic diversity and increased 593 population differentiation in peripheral and overharvested populations of Gigartina skottsbergii (Rhodophyta, Gigartinales) in southern Chile. J Phycol 40:454-462

Felsenstein J (1985) Phylogenies and the comparative methods. Am Nat 125:1-15

Fraser Cl, Thiel M, Spencer HG, Waters JM (2010) Contemporary habitat discontinuity and historic glacial ice drive genetic divergence in Chilean kelp. BMC Evol Biol 10:12

Fraser Cl, Nikula R, Ruzzante DE, Waters JM (2012) Poleward bound: biological impacts of Southern Hemisphere glaciation. Trends Ecol Evol 27:462-471

Fraser Cl, Zuccarello GC, Spencer HG, Salvatore LC, Garcia GR, Waters JM (2013) Genetic affinities between trans-oceanic populations of non-buoyant macroalgae in the high latitudes of the Southern Hemisphere. PlosONE 8:7

Fredericq S, Lopez-Bautista J (2002) Characterization and phylogenetic position of the red alga 604 605 Besa papillaeformis Setchell: an example of progenetic heterochrony? Constancea

Fu YX (1997) Statistical tests of neutrality of mutations against population growth, hitchhiking 607 and background selection. Genetics 147:915-925

Gavio B, Fredericq S (2002) Grateloupia turuturu (Halymeniaceae, Rhodophyta) is the correct 609 name of the nonnative species in the Atlantic known as Grateloupia doryphora. Eur J Phycol 37:349-359 
González-Wevar CA, Nakano T, Cañete JI, Poulin E (2010) Molecular phylogeny and historical biogeography of Nacella (Patellogastropoda: Nacellidae) in the Southern Ocean. Mol Phy Evol 56:115-124

González-Wevar CA, Diaz A, Gerard K, Cañete JL, Poulin E (2012a) Divergence time estimations and contrasting patterns of genetic diversity between Antarctic and southern South America benthic invertebrates. Rev Chil Hist Nat 85:445-456

González-Wevar CA, Hune M, Cañete JI, Mansilla A, Nakano T, Poulin E (2012b) Towards a model of postglacial biogeography in shallow marine species along the Patagonian Province: lessons from the limpet Nacella magellanica (Gmelin, 1791). BMC Evol Biol $12: 1$

González-Wevar CA, Saucède T, Morlay SA, Chown SL, Poulin E (2013) Extinction and recolonization of maritime Antarctica in the limpet Nacella concinna (Strebel, 1908) during the last glacial cycle: toward a model of Quaternary biogeography in shallow Antarctic invertebrates. Mol Ecol 22: 5221-5236

Haye PA, Varela Al, Thiel M (2012) Genetic signatures of rafting dispersal in algal-dwelling brooders Limnoria spp. (Isopoda) along the SE Pacific (Chile). Mar Ecol Prog Ser 455:111-122

Hemery LG, Eléaume M, Roussel V, Améziane N, Gallut C, Steinke D, Cruaud C, Couloux A, Wilson NG (2012) Comprehensive sampling reveals circumpolarity and sympatry in seven mitochondrial lineages of the Southern Ocean crinoid species Promachocrinus kerguelensis (Echinodermata). Mol Ecol 21:2502-2518

Hernandez-Kantun JJ, Riosmena-Rodriguez R, Adey WH, Rind F (2014) Analysis of the cox2-3 spacer region for population diversity and taxonomic implications in rhodolith-forming species (Rhodophyta: Corallinales) Phytotaxa 190: 331-354

Hewitt GM (2000) The genetic legacy of the Quaternary ice ages. Nature 405:907-913 
Ho S, Lanfear R, Bromham, Phillips LMJ, Soubrier J, Rodrigo AG, Cooper A (2011) Timedependent rates of molecular evolution. Mol Ecol 20: 3087-3101

Hommersand MH, Fredericq S, Freshwater DW (1994) Phylogenetic systematics and biogeography of the Gigartinaceae (Gigartinales, Rhodophyta) based on sequence analysis of $r b c L$. Bot Mar 37:193-203

Hommersand MH, Fredericq S, Wilson Freshwater D, Hughey J (1999). Recent developments in the systematics of the Gigartinaceae (Gigartinales, Rhodophyta) based on $r b c \mathrm{~L}$ sequence analysis and morphological evidence. Phycol Res, 47:139-151

Hommersand MH, Fredericq S (2003) Biogeography of the marine red algae of the South African West Coast: a molecular approach. In: Chapman ARO, Anderson RJ, Vreeland VJ and Davison IR (eds) Proceedings of the XVIIth International Seaweed Symposium. Oxford University Press, Oxford, UK

Hommersand MH, Moe RL, Amsler CD, Fredericq S (2009) Notes on the systematics and biogeographical relationships of Antarctic and sub-Antarctic Rhodophyta with descriptions of four new genera and five new species. Bot Mar 52: 509-534

Huelsenbeck JP, Ronquist F (2001) MRBAYES: Bayesian inference of phylogeny. Bioinformatics $17: 754-755$

Hulton NRJ, Sugden DE, Payne A, Clapperton CM (1994) Glacier modeling and the climate of Patagonia during the last glacial maximum. Quat Res 42:1-19

Hulton NRJ, Purves RS, McCulloch RD, Sugden DE, Bentley MJ (2002) The Last Glacial Maximum and deglaciation in southern South America. Quat Sci Rev 21:233-241

Jakob SS, Martinez-Meyer H, Blattner FR (2009) Phylogeographic analyses and paleodistribution modeling indicate Pleistocene in situ survival of Hordeum species (Poaceae) in Southern Patagonia without genetic or spatial restriction, Mol Biol Evol 26:907-923 
661

662

663

664

665

666

667

668

669

670

671

672

673

674

675

676

677

678

679

680

681

682

683

684

685

686

Janosik AM, Mahon AR, Halanych KM (2011) Evolutionary history of Southern Ocean Odontaster sea star species (Odontasteridae; Asteroidea). Polar Biol 34: 575-586.

Jobb G, Von Haeseler A, Strimmer K (2004) TREEFINDER: a powerful graphical analysis environment for molecular phylogenetics. BMC Evol Biol 4:18

Kamiya M, Zuccarello GC, West JA (2004) Phylogeography of Calaglossa leprieurii and related species (Delesseriaceae, Rhodophyta) based on the rbcL gene sequences. Jpn J Phycol $52: 147-151$

Krabbe K, Leese F, Mayer C, Tollrian R, Held C (2010) Cryptic mitochondrial lineages in the widespread pycnogonid Colossendeis megalonyx Hoek, 1881 from Antarctic and Subantarctic waters. Polar Biol 33:281-292

Kuhner MK (2006) LAMARC 2.0: maximum likelihood and Bayesian estimation of population parameters. Bioinformatics 22:768-770

Kussakin OG (1973) Peculiarities of the geographical and vertical distribution of marine isopods and the problem of deep-sea fauna origin. Mar Biol 23:19-34

Lawver LA, Gahagan LM (1998) Opening of Drake Passage and its impact on Cenozoic ocean circulation. Oxford Monographs on Geology and Geophysics 39:212-226

Linse K, Griffiths HJ, Barnes DKA, Clarke A (2006) Biodiversity and biogeography of Antarctic and sub-Antarctic mollusca. Deep-Sea Res II 53:985-1008

Mahon AR, Thornhill DJ, Norenburg JL, Halanych KM (2010) DNA uncovers Antarctic nemertean biodiversity and exposes a decades-old cold case of asymmetric inventory. Polar Biol 33:193-202

McCarthy C (1997) Chromas v1.4 computer package. Griffith University, Australia

Mclvor L, Maggs CA, Provan J, Stanhope MJ (2001) rbcL sequences reveal multiple cryptic introductions of the Japanese red alga Polysiphonia harveyi. Mol Ecol 10:911-919

Moffat C, Beardsley RC, Owen B, van Lipzig N (2008) A first description of the Antarctic Peninsula Coastal Current. Deep-Sea Res II 55:277-293 
Montecinos A, Broitman BR, Faugeron S, Haye PA, Tellier F, Guillemin ML (2012) Species replacement along a linear coastal habitat: phylogeography and speciation in the red alga Mazzaella laminarioides along the south east pacific. BMC Evol Biol 12:17

Nei M, Li WH (1979) Mathematical model for studying genetic variation in terms of restriction endonucleases. Proc Natl Acad Sci USA 76:5260-5273

Nei M (1987) Molecular Evolutionary Genetics. Columbia University Press, New York, USA

Nikula R, Fraser Cl, Spencer HG, Waters JM (2010) Circumpolar dispersal by rafting in two subantarctic kelp-dwelling crustaceans Mar Ecol Prog Ser 405:221-230

Piriz ML (1996) Phenology of a Gigartina skottsbergii Setchell et Gardner population in Chubut Province (Argentina). Bot Mar 39: 311-316

Posada D, Crandall KA (1998) MODELTEST; testing the model of DNA substitution. Bioinformatics Application Note 14:817-818

Poulin E, González-Wevar C, Diaz A, Gerard K, Hune M (2014) Divergence between Antarctic and South American marine invertebrates: What molecular biology tells us about Scotia Arc geodynamics and the intensification of the Antarctic Circumpolar Current. Global Planet Change 123:392-399

Provan J, Bennett KD (2008) Phylogeographic insights into cryptic glacial refugia. Trends Ecol Evol 23:564-571

Ramirez ME, Santelices B (1991) Catalogo de algas marinas bentónicas de la costa temperada del Pacífico de Sudamérica. Monogr Biol 5:247-52

Raupach MJ, Thatje S, Dambach J, Rehm P, Misof B, Leese F (2010) Genetic homogeneity and circum-Antarctic distribution of two benthic shrimp species of the Southern Ocean, Chorismus antarcticus and Nematocarcinus lanceopes. Mar Biol 157:1783-1797

Roger AR, Harpending H (1992) Population growth makes waves in the distribution of pairwise genetic differences. Mol Biol Evol 9:552-569 
Rogers AD, Murphy EJ, Johnston NM, Clarke A (2007) Introduction. Antarctic ecology: from genes to ecosystems. Part 2. Evolution, diversity and functional ecology. Phil Trans R Soc B 362: 2187-2189

Santelices B (1988) Algas marínas de Chile. Distribución, ecología, utilización y diversidad. Ediciones Universidad Católica de Chile, Santiago, Chile

Stupnikova AN, Molodtsova TN, Mugue NS, Neretina TV (2013) Genetic variability of the Metridia lucens complex (Copepoda) in the Southern Ocean. J Mar Syst 128:175-184

Tajima F (1989) Statistical method for testing the neutral mutation hypothesis by DNA polymorphism. Genetics 123:585-595

Tamura K, Peterson D, Peterson N, Stecher G, Nei M, Kumar S (2011) MEGA5: Molecular Evolutionary Genetics Analysis Using Maximum Likelihood, Evolutionary Distance, and Maximum Parsimony Methods. Mol Biol Evol 28: 2731-2739

Tavares M, de Melo GAS. (2004) Discovery of the first known benthic invasive species in the Southern Ocean: the North Atlantic spider crab Hyas araneus found in the Antarctic Peninsula. Antarct Sci 16:129-131

Thatje S, Fuentes V (2003) First record of anomuran and brachyuran larvae (Crustacea: Decapoda) from Antarctic waters. Polar Biol 26:279-282

Thatje S, Hillenbrand C-D, Larter R (2005) On the origin of Antarctic marine benthic community structure. Trends Ecol Evol 20:534-540

Thatje S, Hillenbrand CD, Mackensen A, Larter R (2008) Life hung by a thread: endurance of Antarctic fauna in glacial periods. Ecology 89:682-692

Thorpe SE, Heywood KJ, Stevens DP, Brandon MA (2004) Tracking passive drifters in a high resolution ocean model: implications for interannual variability of larval krill transport to South Georgia. Deep-Sea Res I 51:909-920

Valdovinos C, Navarrete SA, Marquet PA (2003) Mollusk species diversity in the Southeastern Pacific: why are there more species towards the pole? Ecography 26:139-144 
Vianna JA, Medina-Vogel G, Chehebar C, Sielfeld W, Olavarria C, Faugeron S (2011) Phylogeography of the Patagonian otter Lontra provocax: adaptive divergence to marine habitat or signature of southern glacial refugia? BMC Evol Biol 11:12

Weis A, Meyer R, Dietz L, Domel JS, Leese F and Melzer, RR (2014) Pallenopsis patagonica (Hoek, 1881) - a species complex revealed by morphology and DNA barcoding, with description of a new species of Pallenopsis Wilson, 1881. Zool J Linn Soc 170:110-131

Westermeier R, Aguilar A, Sigel J, Quintanilla J, Morales J (1999) Biological basis for the

Wulff A, Iken K, Quartino ML, Al-Handal A, Wiencke C, Clayton MN (2009) Biodiversity, biogeography and zonation of marine benthic micro- and macroalgae in the Arctic and Antarctic. Bot Mar 52:491-507

Zemlak TS, Walde SJ, Habit EM, Ruzzante DE (2011) Climate-induced changes to the ancestral population size of two Patagonian galaxiids: the influence of glacial cycling. Mol Ecol $20: 5280-5294$

Zuccarello GC, Burger G, West JA, King ARJ (1999) A mitochondrial marker for red algal intraspecific relationships. Mol Ecol 8:1443-1447 
Cox23

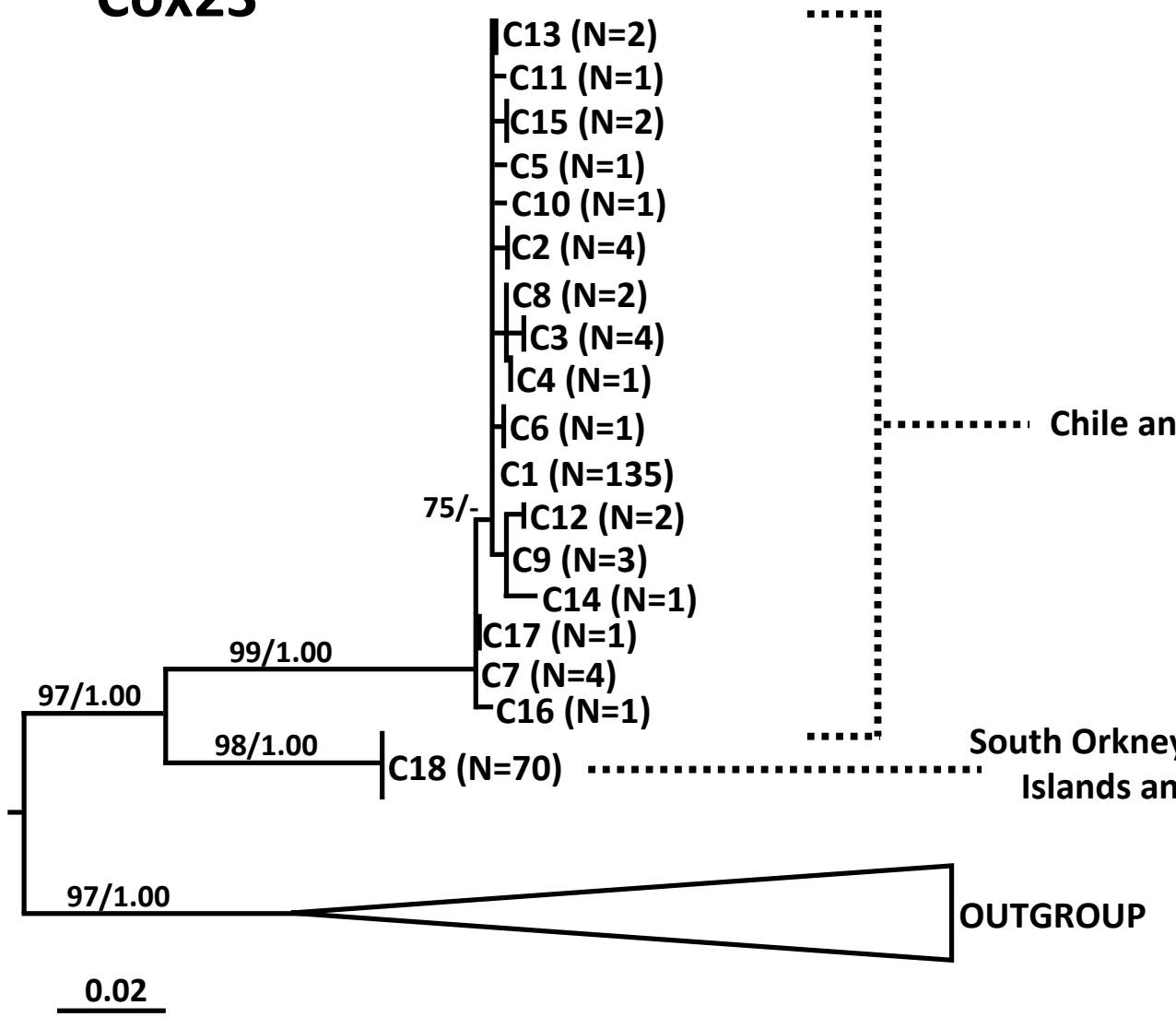

$r b c L$

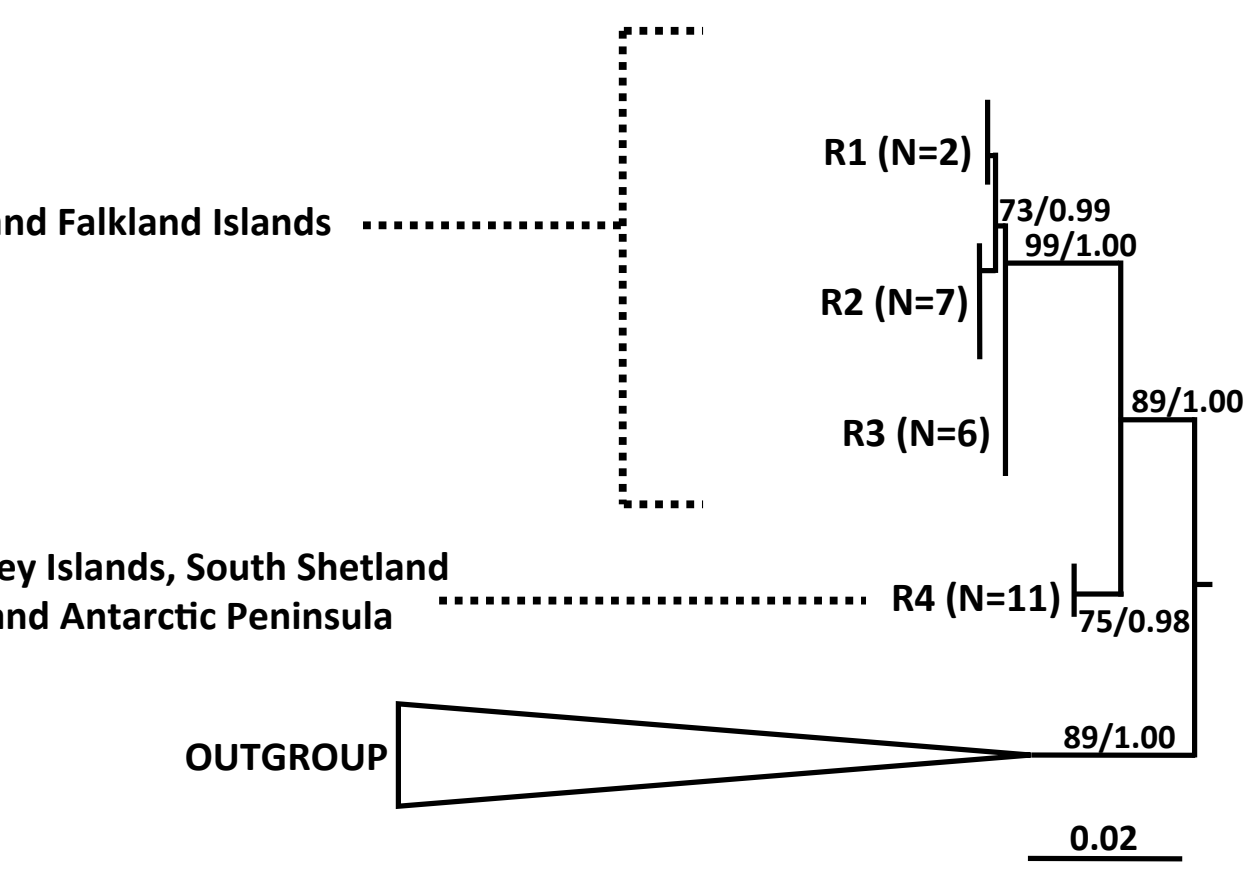



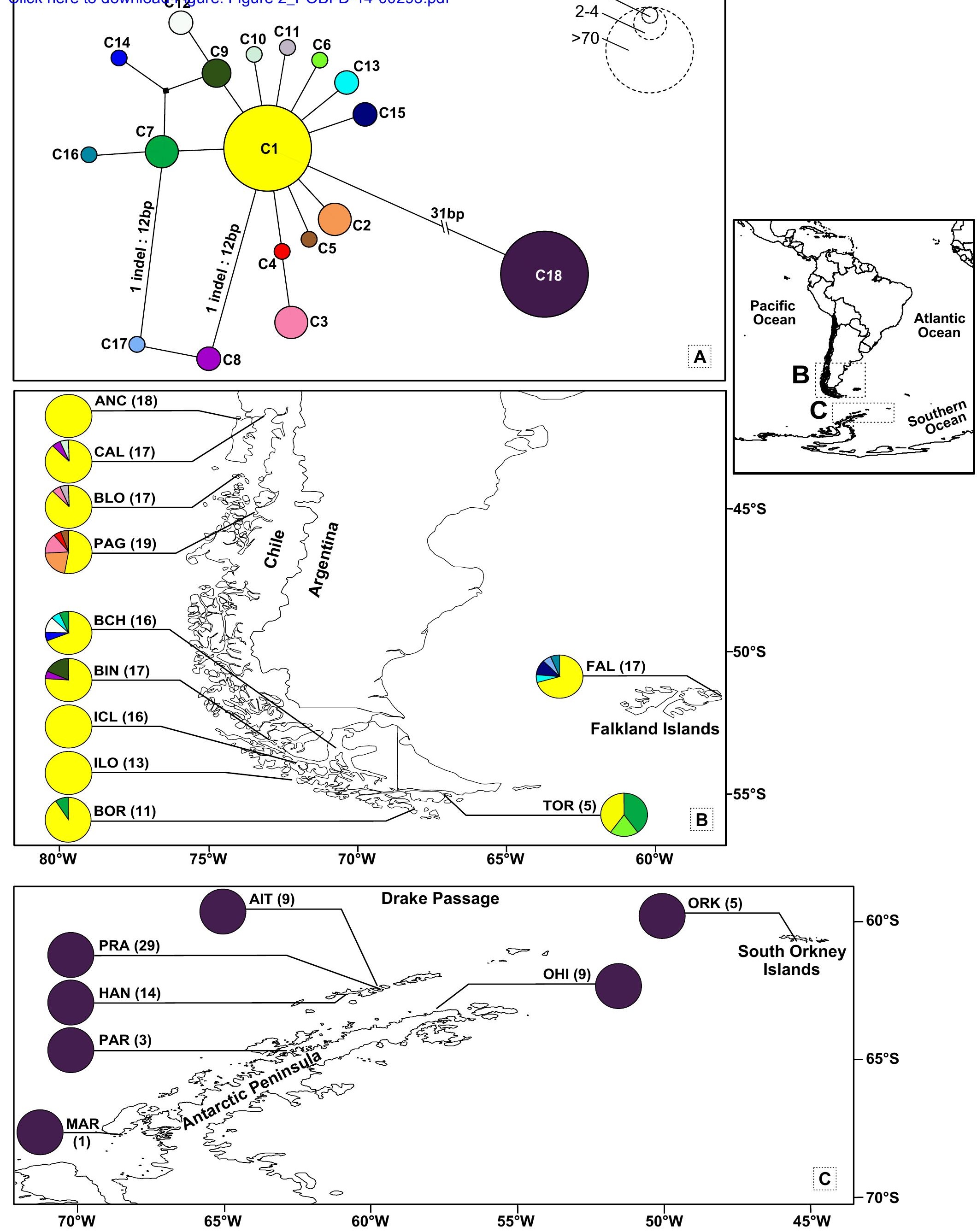


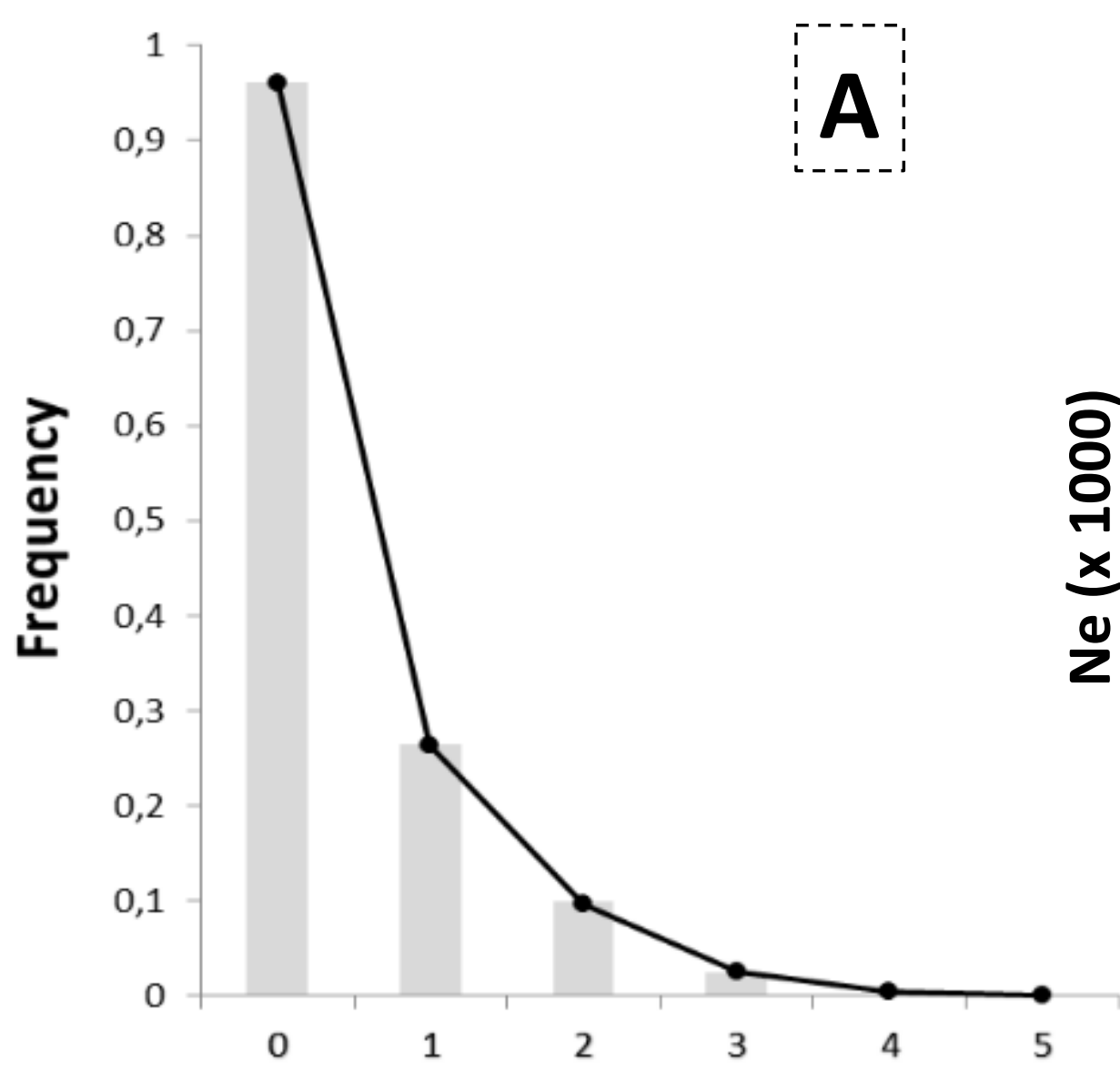

Number of pairwise differences

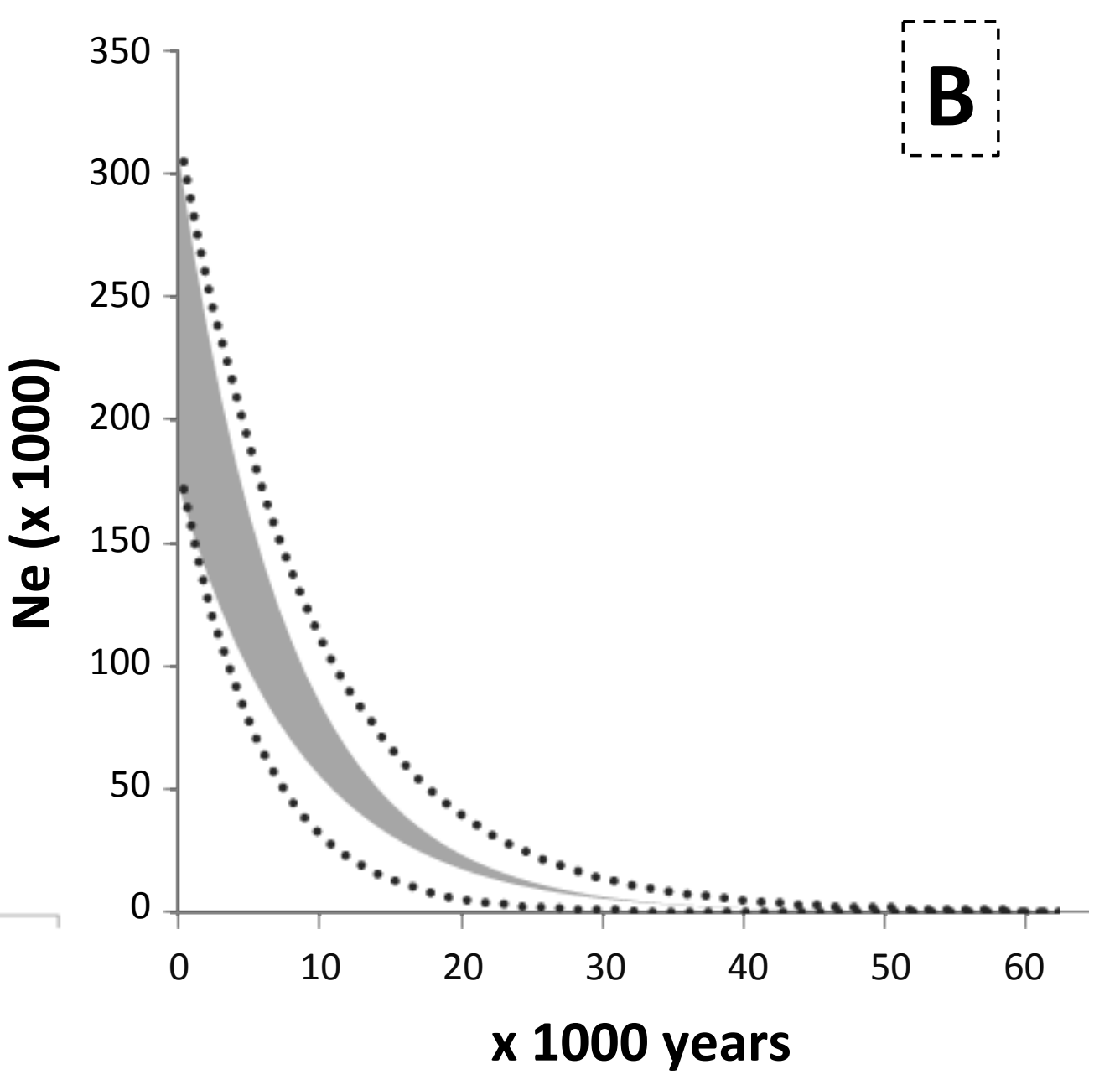


Table1: Sampling sites of G. skottsbergii and associated genetic diversity for two molecular markers (cox23: mitochondrial; rbcL: chloroplast). For each site, the abbreviation (code) and the geographic coordinates are indicated. For more information on molecular diversity indices see foot note references.

\begin{tabular}{|c|c|c|c|c|c|c|c|c|c|c|c|c|}
\hline \multirow[b]{2}{*}{ Sampling site } & \multirow[b]{2}{*}{ Code } & \multirow[b]{2}{*}{ Coordinates } & \multicolumn{6}{|c|}{ Cox 23} & \multirow[b]{2}{*}{ Hap. } & \multicolumn{3}{|r|}{$r b c \mathrm{~L}$} \\
\hline & & & $\mathrm{N}$ & $\mathrm{nH}$ & $\mathrm{Hd}$ & $\pi(.10-2)$ & $\mathrm{S}$ & nHpriv & & $\mathrm{N}$ & $\mathrm{nH}$ & Hap. \\
\hline \multicolumn{13}{|l|}{ Chile } \\
\hline Ancud & ANC & $41^{\circ} 51^{\prime} \mathrm{S} / 73^{\circ} 47^{\prime} \mathrm{W}$ & 18 & 1 & 0 & 0 & 0 & 0 & $\mathrm{C} 1(18)$ & 2 & 1 & $\mathbf{R} 1(2)$ \\
\hline Calbuco & CAL & $41^{\circ} 48^{\prime} \mathrm{S} / 73^{\circ} 13^{\prime} \mathrm{W}$ & 17 & 3 & 0.18 & 0.44 & 13 & 1 & $\mathrm{C} 1(15), \mathrm{C} 8(1), \mathbf{C 1 0}(\mathbf{1})$ & & & \\
\hline Bahia Low & BLO & $43^{\circ} 47^{\prime} \mathrm{S} / 73^{\circ} 58^{\prime} \mathrm{W}$ & 17 & 3 & 0.23 & 0.10 & 3 & 1 & C1(15), C3(1), C11(1) & 1 & 1 & $\mathrm{R} 2(1)$ \\
\hline Puerto Aguirre & PAG & $45^{\circ} 10^{\prime} \mathrm{S} / 73^{\circ} 32^{\prime} \mathrm{W}$ & 19 & 5 & 0.68 & 0.31 & 4 & 3 & $\mathrm{C} 1(10), \mathbf{C 2}(4), \mathrm{C} 3(3), \mathbf{C 4}(\mathbf{1}), \mathbf{C 5}(\mathbf{1})$ & & & \\
\hline Bahia Chilota & $\mathrm{BCH}$ & $53^{\circ} 20^{\prime} \mathrm{S} / 70^{\circ} 43^{\prime} \mathrm{W}$ & 16 & 5 & 0.53 & 0.30 & 5 & 2 & $\begin{array}{l}\mathrm{C} 1(11), \mathrm{C} 7(1), \mathbf{C 1 2}(2), \mathrm{C} 13(1), \\
\mathbf{C 1 4}(\mathbf{1})\end{array}$ & 2 & 1 & $\mathrm{R} 2(2)$ \\
\hline Bahia Inútil & BIN & $53^{\circ} 10^{\prime} \mathrm{S} / 72^{\circ} 55^{\prime} \mathrm{W}$ & 17 & 3 & 1.72 & 0.49 & 13 & 1 & $\mathrm{C} 1(13), \mathrm{C} 8(1), \mathbf{C 9}(3)$ & 2 & 1 & $\mathrm{R} 2(2)$ \\
\hline Isla clarence & ICL & $54^{\circ} 03^{\prime} \mathrm{S} / 71^{\circ} 58^{\prime} \mathrm{W}$ & 16 & 1 & 0 & 0 & 0 & 0 & $\mathrm{C} 1(16)$ & 1 & 1 & $\mathrm{R} 2(1)$ \\
\hline Isla London & ILO & $54^{\circ} 57^{\prime} \mathrm{S} / 72^{\circ} 20^{\prime} \mathrm{W}$ & 13 & 1 & 0 & 0 & 0 & 0 & $\mathrm{C} 1(13)$ & 1 & 1 & $\mathrm{R} 2(1)$ \\
\hline Bahía Orange & BOR & $55^{\circ} 31^{\prime} \mathrm{S} / 68^{\circ} 08^{\prime} \mathrm{W}$ & 11 & 2 & 0.18 & 0.05 & 1 & 0 & $\mathrm{C} 1(10), \mathrm{C} 7(1)$ & 1 & 1 & $\mathrm{R} 3(1)$ \\
\hline Puerto Toro & TOR & $55^{\circ} 06^{\prime} \mathrm{S} / 67^{\circ} 06^{\prime} \mathrm{W}$ & 5 & 3 & 0.80 & 0.29 & 2 & 1 & $\mathrm{C} 1(2), \mathbf{C 6}(\mathbf{1}), \mathrm{C} 7(2)$ & & & \\
\hline \multicolumn{13}{|l|}{$\begin{array}{l}\text { Falkland } \\
\text { Islands }\end{array}$} \\
\hline Falkland & FAL & $51^{\circ} 37^{\prime} \mathrm{S} / 57^{\circ} 45^{\prime} \mathrm{W}$ & 17 & 5 & 0.51 & 0.59 & 15 & 3 & $\begin{array}{l}\mathrm{C} 1(12), \mathrm{C} 13(1), \mathbf{C 1 5}(2), \mathbf{C 1 6}(1), \\
\text { C17(1) }\end{array}$ & 5 & 1 & $\mathrm{R} 3(5)$ \\
\hline \multicolumn{13}{|l|}{$\begin{array}{l}\text { South Orkney } \\
\text { Islands }\end{array}$} \\
\hline Orkney & ORK & $60^{\circ} 44^{\prime} \mathrm{S} / 45^{\circ} 37^{\prime} \mathrm{W}$ & 5 & 1 & 0 & 0 & 0 & 0 & $\mathrm{C} 18(5)$ & & & \\
\hline \multicolumn{13}{|l|}{$\begin{array}{l}\text { South Shetland } \\
\text { Islands }\end{array}$} \\
\hline Punta Hanna & HAN & $62^{\circ} 39^{\prime} \mathrm{S} / 60^{\circ} 38^{\prime} \mathrm{W}$ & 14 & 1 & 0 & 0 & 0 & 0 & C18(14) & 1 & 1 & $\mathrm{R} 4(1)$ \\
\hline Punta Prat & PRA & $62^{\circ} 28^{\prime} \mathrm{S} / 59^{\circ} 40^{\prime} \mathrm{W}$ & 29 & 1 & 0 & 0 & 0 & 0 & C18(29) & 2 & 1 & $\mathrm{R} 4(2)$ \\
\hline Isla Aitcho & AIT & $62^{\circ} 25^{\prime} \mathrm{S} / 59^{\circ} 44^{\prime} \mathrm{W}$ & 9 & 1 & 0 & 0 & 0 & 0 & $\mathrm{C} 18(9)$ & 1 & 1 & $\mathrm{R} 4(1)$ \\
\hline \multicolumn{13}{|l|}{$\begin{array}{l}\text { Antarctic } \\
\text { Peninsula }\end{array}$} \\
\hline O'Higgins & $\mathrm{OHI}$ & $63^{\circ} 18^{\prime} \mathrm{S} / 57^{\circ} 53^{\prime} \mathrm{W}$ & 9 & 1 & 0 & 0 & 0 & 0 & $\mathrm{C} 18(9)$ & 4 & 1 & $\mathrm{R} 4(4)$ \\
\hline Paradise Bay & PAR & $64^{\circ} 50^{\prime} \mathrm{S} / 62^{\circ} 52^{\prime} \mathrm{W}$ & 3 & 1 & 0 & 0 & 0 & 0 & C18(3) & 2 & 1 & $\mathrm{R} 4(2)$ \\
\hline Marguerite Bay & MAR & $67^{\circ} 45^{\prime} \mathrm{S} / 68^{\circ} 52^{\prime} \mathrm{W}$ & 1 & 1 & 0 & 0 & 0 & 0 & $\mathrm{C} 18(1)$ & 1 & 1 & $\mathrm{R} 4(1)$ \\
\hline $\begin{array}{l}\text { Chile and } \\
\text { Falkland } \\
\text { Antarctic }\end{array}$ & & & 166 & 17 & 0.34 & 1.05 & 24 & & & 15 & 3 & \\
\hline $\begin{array}{l}\text { Peninsula and } \\
\text { Islands }\end{array}$ & & & 70 & 1 & 0 & 0 & 0 & & & 11 & 1 & \\
\hline
\end{tabular}

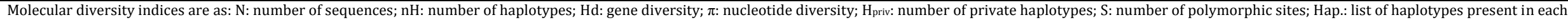
population. In the haplotype list the name of the haplotype is directly followed by the number of sampled individuals presenting the haplotype between parenthesis and private haplotype are noted in bold characters. 
Electronic Supplementary Material
Click here to download Electronic S

Electronic Supplementary Material
Click here to download Electronic Supplementary Material: Online Resource 1_POBI-D-14-00293.pdf

Supp

(1)

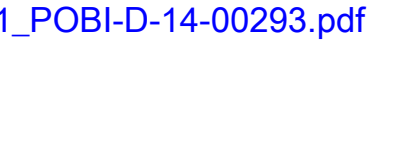
(1) (1) (1) $\sqrt{10}$ (1) (1) (1) (1) (1) (1) (1) 
Electronic Supplementary Material
Click here to download Electronic S

Electronic Supplementary Material
Click here to download Electronic Supplementary Material: Online Resource 2_POBI-D-14-00293.pdf

(n)

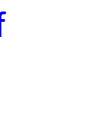

